\title{
Similar Biologics: Global Opportunities and Issues
}

\author{
Prasanta Kumar Ghosh \\ Managing Partner, Sompradip Publishers and Consultants, Block C2B, Flat 5A, Janakpuri, New Delhi, India. \\ Received, December5, 2016; Revised, December18, 2016; Accepted, January1, 2017; Published, January 1, 2017.
}

\begin{abstract}
The invention and use of a large number of biologics during the last three decades for treating various deficiencies and chronic disorders has resulted in great benefit to human health. Abundant use of these biologics has been considerably constrained due to the reasons of their increased prices, charged by the inventors up to the time up to which their use were/are protected by intellectual property rights (IPR).Some of these biologics are presently being manufactured by the existing and newer companies as "similar biologics" after the IPR on these products have expired and as a result the prices of several such medicines are coming down. "Similar biologics" are also referred to as "biosimilars" and other related names in different parts of the world. The regulatory authorities of different countries have authorized use of "similar biologics" based on comparative evaluation of each of such medicines with the inventor's biologics; these are approved when considered to be closely similar to the inventor's biologics in properties, quality and efficacy. By 2020 , a dozen of "inventor's biologicals" having estimated market sale-value of over USD 79 billion are going out of protection of IPR. This would drive entrepreneurs to enter in to the field and the prices are going to crash considerably due to market competition. In course of time more "biosimilars" would go out of IPR. Different proactive governments and the regulatory agencies all over the world are trying to harness the existing and future opportunities by creating regulatory guidelines to ease faster authorization for use of "similar biologics" in their territories. Up to the present time, a small number of "similar biologics" have been approved for use in different countries all over the major parts of the world. More efficient technologies for manufacture of "similar biologics" are also getting developed. Together, these efforts are anticipated to ease the availability of "similar biologics" at more affordable prices to the users/ payers the world over.
\end{abstract}

This article is open to POST-PUBLICATION REVIEW. Registered readers (see "For Readers") may comment by clicking on ABSTRACT on the issue's contents page.

\section{INTRODUCTION}

Modern biological drugs or biologics are manufactured by deploying recombinant DNA(r DNA) technology. Over the past three decades the development of biological drugs has experienced continuous growth. Chemically, such drugs are complex molecular substances which are produced by and within living cells of prokaryotic or eukaryotic origin. For the production of certain of such drugs, transgenic animals and plants are used. The cellular machinery of living entities synthesize such substances based on the 'commands' introduced by the scientists within the living bodies by utilizing $\mathrm{r}$ DNA technology. The molecular substances are 100 to 1000 times bigger in size as compared to the active pharmaceutical ingredients (APIs) that are used for the manufacture of generic pharmaceutical formulations. Almost all such biologically manipulated man-made molecular substances are initially protected under Intellectual Property Rights (IPR) by the inventors or their assignees.
IPR stipulates protection in countries where such rights have been taken. IPR becomes an expensive way to protect an invention if the invention is not exploited by the owner; many inventors therefore do not invest to protect their invention in every country. Earlier, protection was usually taken by the inventors in countries where inventors felt that the invention was saleable and the demands for the products emanating from the exploitation of the invention were anticipated to be high. Presently however the span of protection of inventions that are anticipated to be industrially exploitable fast is extended on a much wider canvas to cover as many countries as have demand for such products and where scientific capabilities of manufacturing such products exist in their territories, especially after the enactment of the provisions of World Trade Organization (WTO) in Member countries

Corresponding Author: Prasanta Kumar Ghosh; Managing Partner, Sompradip Publishers and Consultants, Block C2B, Flat 5A, Janakpuri, New Delhi, India; E-mail: sompradip.publishers@yahoo.com 
For the protection of inventions in Member countries, WTO has a uniform provision. Most countries in the world are presently members of WTO.

Protein-based biological drugs comprising mainly of simple or carbohydrate ligand-modified substances have a wide range of therapeutic applications. The business is very large in terms of global sale and therefore entrepreneurs have eyes on this business. The proprietary rights on such biological drugs are vested upon the inventors or their assignees as per the conditions of IPR.

As regards the contributions of the existing modern biologics in human welfare, these medicines have assisted significantly during the last two decades in treating chronic diseases including cancer. Use of various kinds of insulin manufactured through recombinant DNA technology along with other anti-diabetic drugs have resulted in the control of plasma glucose within healthy limits and death rates of diabetic patients between 1997 and 2006 have substantially fallen (2). Insulin has played a major role in such endeavour. Use of a large number of biological medicines to treat rheumatoid arthritis such as tocilizumab, certolizumab, etanercept, adalimumab, anakinra, abatacept, infliximab, rituximab, golimumab and tofacitinib has enabled clinical remission of the disease almost completely and has contributed to great human benefits; results with etanercept had been amazing(3). Treating cardio-vascular diseases by use of biological medicines such as thrombolytic agents like streptokinase, urokinase and tissue plasminogen activator, and monoclonal antibodies like abciximab (platelet aggregation inhibitor used usually during and after coronary artery procedures like angioplasty to prevent platelets aggregation) have saved many lives. Biological drugs have resulted in reduction in death rates from cardiovascular diseases by about 31\% between 1998 and 2008 in the United States of America(USA or US) (4). Development and use of erythropoietin produced by modern biotechnology has reduced the need for blood transfusion in anaemic patients of different kinds including cancer patients and have reduced hospital days, thereby benefitting the society. This medicine has also prolonged lives of many terminally ill patients. Incurable viral diseases such as HBV and HCV have been controllable by use of a wide range of modern biologics such as interferons and pegylated interferons. A large number of monoclonal antibodies such as Nimotuzumab, Rituximab, Trastuzumab, Cetuximab etc. are continuing to provide substantial life expectancy gains. In US, the death due to all kinds of cancer has come down steadily by $1.5 \%$ per year from and during 2000 2013 , which is a reduction of around $17 \%$ over this period and is considered highly significant(5). Overall, the use of biological drugs has contributed to increasing life expectancy, decreasing disability and improvement in the quality of life (6).Several other independent studies have also shown that the biologic drugs have made most significant impact in prolonging and improving the quality of life of patients suffering from chronic disease conditions(7-11). Therefore, wherever the burden of incidence of such diseases is showing increase, societal efforts require intensification to enable the availability and use of such medicines to the affected. Presently, because of increased costs of such medicines and the limited means of the payers in the poor countries, the situation becomes most vulnerable in families having to pay for the costs. The governments in poor countries also do not have adequate funds to make the necessary supply of such drugs to its citizens and in most countries the patients are the payers for the cost of their treatment.

Another dimension of human welfare has surfaced profoundly in all parts of the world which emanates from the increase in the number of elderly people (over $60 \mathrm{y}$ ) where providing a better quality of life to such population usually suffering from multiple chronic ailments is becoming a major problem worldwide; such persons infected with multiple chronic diseases would increase gradually over the years. Presently, little published information exists on how chronic conditions cluster and how judicious choice of medicines can be made to treat such conditions simultaneously. At the moment diabetes, cardio-pulmonary diseases, hypertension, arthritis, osteoporosis and a wide range of cancer are causes of co-occurrence of chronic diseases. Some empirical relationships of suffering from multiple chronic disease conditions in elderly patients could be associated with metabolic disorder syndrome such as obesity, glucose intolerance, hyperlipidimia and low serum content of high density lipoproteins (low HDL). In such multiple ailments, interrelationships are being worked out by understanding the detailed biology and the clinical manifestations of a group of such patients. This will result in planning for appropriate therapy and the biological medicines would play significant contributions in such endeavour. Such efforts of understanding the linkage among chronic diseases will be comprehended more profoundly in future and biological drugs along with others would contribute to treating such conditions (12). 
In gist, it is anticipated that every country shall try to have abundant supply of cheaper but effective biological drugs in their territory to treat their population suffering from single or multiple chronic diseases.

With the passage of time, when such biological medicines get patent-expired, other new companies would come up and start producing them. Worldwide, the accepted practice for adoption of such patent-expired products for human use in medicines from manufacturers other than the original inventors are based upon proving and providing properties of the products manufactured by the new supplier/s as very similar to the products of the inventor through processes of comparison of the products physico-chemically, biologically and through accepted but limited clinical studies on human subjects. Such products introduced by new companies later-on are named differently in different countries(13-16) such as "biosimilars", "biosimilar products", "follow-on biologics", "similar biologics", "biologics against new biologics", "biocomparables" and "medicamento biologico similar". In India, these products are named as "similar biologics". In several international journals, such products have been termed as "Copycat" (17) and "Knockoff" (18). In this review, the term "similar biologics" has been adopted for these products.

Each authorized "similar biologic" product is named by the manufacturers in their labels or prescribing information by an international nonproprietary name besides their trade name in order to ease precise recognition. The international nonproprietary name (INN) or the core name of the biologic substance is usually the name adopted for the drug substance internationally. The World Health Organization (WHO) had provided an update on INN for biologics (19). As the "similar biologics" are highly similar to their biologic reference products, countries authorizing such substances are also allowing the use of the INN for the "similar biologics" on the label as well as in the prescribing literature. However, very precisely speaking, "similar biologics" are indeed not identical to the reference biologics. As the biologics are large macro-molecules and their structural complexities emanate from variations in the genetic processing entities as well as the manufacturing and downstream processing variations among manufacturers, there can be variations among the reference biologics and the "similar biologics" even though the difference cannot often be quantified at the beginning by utilizing the currently available scientific tools. But such non-noticeable differences might manifest adverse reactions on long-term use. "Similar biologics" are therefore, needed to be identified precisely for the monitoring of post-approval safety in order to identify and evaluate adverse reactions which may surface later on while using the products over a period of time, and which were not reported earlier (a phenomenon about which keeping a vigilance is called pharmacovigilance).For all new drug formulations, it is a practice to conduct pharmacovigilance studies to be vigilant about emergence of adverse effects on long-term use. Consequently, in some countries especially in developed counties strong bias exists to distinguish a "similar biologic" product from its reference product and other "similar biologics". Tackling this situation requires a standardized approach. One approach taken by some countries is through modification of the accepted INN.

Presently, among all nations, the United States Food and Drug Administration (USFDA) have taken a position in the context of INN naming of "similar biologics". In their guidance (20), the licensed similar biological products will include a core name and one designated suffix composed of four lowercase letters will be added to the core name of each product and will be attached with a hyphen. The core name of the biological product will be the name adopted by the United States Adopted Names (USAN) Council for the drug substance (21), which would generally be the INN for the reference biologics. Subsequently, the USFDA announced (22) that instead of one suffix, companies would be allowed to propose ten different suffixes, of which one shall be chosen and authorized by USFDA for the applicant to use in its literature.

Besides the present system of naming adopted by the USFDA, another way for addressing the issue may perhaps be through the use of US National Drug Codes (NDCs) with some modifications. In US, the NDCs are used for providing information about pharmaceutical products (23) although such codes are not compulsorily used in all the states throughout US. However, NDC's information is not presently used compulsorily for adverse events (AE) studies and perhaps there is inadequate familiarity among the medical practitioners about NDCs (24-25). However, it can be explore if the use of NDCs can be extended to identify "similar biologics" and if this can be made universal.

Some other countries such as Australia and Japan are tackling the issue in a different way, essentially by modifying the INN. Australia is in the process of coming out with its naming policy 
for "similar biologics". In Japan a suffix of "BS" is added to the INN to denote a biosimilar product. The naming policy of "similar biologics" is thus not yet universally consistent and congruent. One group has suggested that a US biosimilar naming policy along with a distinguishable prefix or suffix to the non-proprietary name of the reference product be used (26). In order to rationalize a uniform naming system for all "similar biologics" throughout the world, there is a need to evolve a uniform policy for all countries with a view to foster similar understanding for such products globally. It is useful to conjecture that any policy adopted for this purpose should not in any way promote quality-difference concept of such products with the reference biologics.

One alternative way is to prefix or suffix a code for each new-entrant "similar biologics" on the brand name instead on the INN; for companies introducing "similar biologics" only in INN, the prefix or suffix can be added on the INN for them.

In this paper, the business opportunities for the existing and the new entrants in the business of "similar biologics" in different countries, the technological choice options, the regulatory procedures to be complied with for marketing and the present status of approval of such products in major countries all over the major parts of the world and the new naming issues of "similar biologics" have been discussed.

\section{METHODOLOGY OF STUDY}

The current global status of "similar biologics" was assessed through an information search strategy which was designed based on information available on the websites of different governments, the WHO, the European Medicines Agency (EMA) and the USFDA. Google and other search engines were used to access information on biosimilars/"similar biologics" such as research and review articles published in international journals. Several keywords were used for conducting the search which includes biosimilars, biopharmaceutical companies, biomedicines, clinical trials in biologics, data-marketing exclusivity, technological processes for biosimilars, patent expiry of monoclonal antibodies and biologics, nomenclature plan of biosimilars etc. The websites of important manufacturers of biologics were also searched. Technological information including productspecific yields was collected through the search engines. Discussions were also conducted with certain knowledgeable Indian manufactures of "similar biologics". The author had hands-on experience in developing and manufacturing aspects of a couple of "similar biologics" in India.

\section{GLOBAL AND NATIONAL MARKET SCENARIO FOR SIMILAR BIOLOGICS}

The global market for "similar biologics" was anticipated to grow to USD 10 billion in 2015(27). The future growth is largely driven by some twelve numbers of "inventor's biologicals" going off patent(28)in USA and Europe by 2020 worth market sale-value of over USD 79 billion which include Adalimumab (Humira),Insulin Glargine(Lantus),Etanercept(Enbrel),Infliximab( Remicade),Rituximab(Mabthera),InsulinAspart(N ovomix,Novorapid),Bevacizumab(Avastin), InterferonBeta1A(Avonex,Rebif),Trastuzumab(H erceptin),GlatiramerAcetate(Copaxone),Pegfilgras tim(Neuiasta) and Ranibizumab (Lucentis). The loss of exclusivity in intellectual property rights would drive the existing as well as the new entrepreneurs to enter in to the field and the prices are going to crash considerably through market competition, once these products are introduced as "similar biologics". In course of time more numbers of "inventor's biologics" would go out of patents protection and therefore the opportunities for the manufacturers of such drugs are anticipated to enlarge.

The number of companies likely to enter into "similar biologics" market would be large even though the numbers in absolute terms would not be enormously large, as the lead time in the development of such products is high, would require high investment costs and the technological complications are intricate. Such "similar biologics" are "different" from "patent-expired small molecules", where (in the latter cases) the developmental requirements are much simpler. "Patent-expired" small molecules are parts of outfits of "generic drugs" manufacturing.

\section{"SIMILAR BIOLOGICS": COMPLEX PRODUCTS BUT ATTRACTIVE FOR ALL COUNTRIES}

"Similar biologics" are biological entities that have been introduces after the inventor's biologics. During the recent times, there has been newer and novel understanding of the molecular and cellular basis of complex diseases such as arthritis, psoriasis, multiple sclerosis, complications of prolonged diabetes, cardiovascular diseases, neurological disorders and a wide range of cancer. In order to contain such disease conditions and to impart better quality of life to the diseased individuals, biological drugs have been invented which have shown much better efficacy over the 
small molecular entities and therefore more emphasis is being made to develop more effective new biological entities. Such biological products are essentially proteins in nature and include a wide range of substances starting from relatively simpler molecules such as protein-based disulphide bond-rich antigens, hormones, glycosilated proteins, pegylated proteins, cytokines, monoclonal antibodies, bispecific antibodies, antibody fragments, antibody-drug conjugates, radio-labelled antibody conjugates, Fcfusion proteins, albumin-binding domain antibodies, carbohydrate antigens, plasmids, nucleic acid-based products and vaccines, cellular products for therapy and gene therapy products , and devices related to cell and gene therapy. In this review, only the protein-based products have been considered which include protein-based disulphide bond-rich antigens, hormones, glycosilated proteins, pegylated proteins, cytokines, monoclonal antibodies, antibody fragments, antibody-drug conjugates of all kinds and albuminbinding domain antibodies. Proteins are polymers of alpha amino (most frequently L- $\alpha$-amino) acids with defined sequences linked by peptide bonds and having usually more than forty alpha amino acids in each molecule but can go even up to 2000 amino acids or more. In these products-baskets, presently there are about 50 therapeutic monoclonal antibodies of inventor's products approved globally and that the turnover of these products in 2013 worldwide was about US\$ 75 billion. It is anticipated that by 2020 , nearly 70 monoclonal antibody products shall be approved globally (29), the turn-over value of which has been estimated at US $\$ 125$ billion at current prices.

As many of the inventor's biologics are going out of patent or have already reached such status, other companies are feeling the urge of getting into the business as fast as possible so as to reap benefits from their sales. However, entering into this business which is highly science based and technology oriented is not easy. All these products in the form of molecules are produced within living cells; such cells can be prokaryotic or eukaryotic in nature and have been modified by use of recombinant DNA technology. Such cells are grown and conditions are so set as to direct such living entities to synthesize these molecules. These molecules are large and often very large in molecular size, presented as alpha amino acid polymers connected by peptide bonds and making them complex in final tertiary or quaternary structures. The primary structures are made up of chemical covalent bonds between and among the alpha amino acids; he primary products are processed by the cellular machinery into secondary, tertiary and sometimes quaternary structures creating contours on their surface as well as within the core, "pockets" of diverse electronrich or electron-deficient as well as hydrophobic or hydrophilic regions. Weaker structural bonds are created by hydrogen bonds, ionic bonds, and van der Waals attractions. Such individual noncovalent bonds are 30-300 times weaker than the covalent bonds but when in contours many numbers of weaker bonds act in parallel, these contribute to holding two or more regions of the polypeptide chain tightly together. The eventually evolved three dimensional structures evince biological activity. Such structural contours are essential and critical for their biological activities as most biological interactions are based on ligandreceptor interactions that trigger the manifestation and/or modulations of diverse biochemical reactions in the cellular environment where these products are active. The active bio-molecules are either a part of the cellular entities or are secreted into the surrounding medium by the living cells that synthesize them. In either case, the isolation process of the active ingredients is complex requiring separating them out in sufficiently pure form, often more than $98 \%$ in purity assessed on sophisticated analytical instruments. It requires great skill to separate out the desired product in such purity when their initial concentration is substantially low (micro gram to milligram gram quantities per litre of cell-soup) and are surrounded by cell debris, other proteins, liquids, salts and different kinds of metabolites generated during the cell growth operations. Because of complex biological environment, part of the target products is likely to be modified through cellular processes of modifications. Besides, the products are associated with contaminants and endotoxins. In order to ensure the presence of exactly the same variance from batch to batch is also another difficult task to establish. The targeted product has to be isolated and purified to the same degree of purity from batch to batch, which is again a task requiring maintenance of stringent conditions in order to eliminate variation in operating conditions from batch to batch. This also requires use of same qualities of input materials which again can lead to variations in results especially if these are agriculture based materials and cannot therefore often be fully defined. In addition, process related variables are also to be minimized to eliminate product quality difference from batch to batch.

High technical skill, strong discipline and maintenance of uniform conditions throughout the processing cycles are the cornerstones for success 
in order to minimize batch to batch variations in the product qualities. In certain types of biologics, the primary products obtained from the cell soup after purification requires further processing invitro in the laboratories under stringent conditions. The biologics are to be authenticated through stringent in-process controls. The final product requires quantitative characterisation by physicochemical and biological testing methods utilizing sophisticated instruments. The processes are usually not generic and vary considerably from product to product even though certain conditions of creating and maintaining the infrastructure facilities are common, emphasizing unidirectional flow of man and materials, maintenance of cleanliness of high standard in the production areas and isolation of the finishing area from other areas so as to minimize the chances of crosscontamination. Once the biologics are ready for conversion into formulations, these are formulated and packed into the finished products. These are released after rigorous quality control endeavour.

Unlike the small molecules where the active pharmaceutical ingredients and the finished formulations manufactured wherefrom are subjected to quality, purity and stability studies, the biologics are subjected to additional checking for potency, immunogenicity, stability and compatibility. For new biologicals, the first-time authorization for sale is imparted by the regulatory authorities only after satisfactory pre-clinical and clinical studies besides the above. For new biologicals, there is often no initial biologic product for use as a standard and therefore their evaluation is more exhaustive and stringent especially on pharmacovigilance information. On the other hand, for "similar biologics" (or biosimilars), pre-clinical studies as well as abbreviated clinical studies are required using the "reference biologic product" as the standard, and therefore becomes simpler. The main difference in the unit cost of new biologicals and "similar biologics" arise from the large difference in the cost of pre-clinical studies and the clinical studies experiments for the former than the costs incurred thereon for the latter.

It can be stated in general that even though the technological inputs and the process requirements for biologics are complex, these can be duplicated with proper inputs of skills, investment and planning. The entrants of "similar biologics" manufacturers are allowed to seek approval at least ten to twelve years (30-32) after the inventor's products are in the market, depending upon whether they are seeking permission in European
Union (EU) or in USA. In other words, the actors of "similar biologics" have enough time to plan.

By proper choice of the product to be manufactured, the investors of "similar biologics" hold the potential of reaching high business volume within a short period of introduction of their products in the market as the market volume is very large and a part of it can be captured; the major driving force for entering in to this sector is that the profitability in the sector is high for the first entrants and therefore ensuring fastness in every aspects of the planning and implementation is important.

Setting up of "similar biologics" industry would ensure the availability of such drugs from multiple sources resulting in market competition and therefore, the prices would also be cheaper and more affordable than when supplied by the "inventors". The impression all over the world is that the "inventors" have been charging exorbitantly high prices for such drugs till the patent rights are enforceable (33) and as a result such drugs are often unaffordable by a common man. In many countries while the biotherapeutic products purchased by the Government represented (in dosage units) a small percentage of prescribed medicines for their people, in terms of money spent these accounted for substantial portion of the total expenses. In Brazil, biotherapeutic products represented $2 \%$ of the medicines prescribed but accounted for $41 \%$ of the annual budget of the Ministry of Health of that country (34). In EU region, the first "similar biologics" was approved in April 2006 (Omnitrope of Sandoz, which is somatropin); the EU thereby acquired more practical experience in the use of "similar biologics" along with the "reference products". It was found in EU region that up to the present time, the prices of "similar biologics" were $20-30 \%$ cheaper (35) than their "reference products", thereby contributing to substantial saving in treatment costs.

The "similar biologics" approved by the European Medicines Agency (EMA) up to the present time were seven separate classes(36)of "similar biologics" namely human growth hormone (somatropin),erythropoiesis stimulating agents (erythropoietin in its natural and its long acting versions),granulocyte colony stimulating factor (G-CSF also known as filgrastim) as well as its pegylated form, follitropin alpha, infliximab, insulin glargine and etanercept.EU introduced the EMA pathway, which is in vogue for more than a decade. In EU "similar biologics" have impacted several European countries in terms of competitive performance in healthcare systems, cost savings 
and gain in substantial market share of and from the sale of "reference products". A study based on the audit data from Intercontinental Marketing Services (IMS) on two of the above classes of drugs namely erythropoiesis stimulating agents in various forms (erythropoietin in its natural and its long acting versions) and the granulocyte colony stimulating factor (G-CSF) as well as its pegylated long-acting form during 2009-2011 in five EU countries namely Germany, United Kingdom, Sweden, France and Italy was conducted. The results showed that due to cheaper unit prices of "similar biologics" resulting in cost saving, these products acquired significant shares of the market relative to the market shares of the corresponding "reference products" for both the first generation products as well as for the long-lasting second generation products; the latter products were able to acquire more share of the market. The indications from the analysis were that manufacturers of "similar biologics" would be capturing sizeable part of the market of "reference products", but at the same time would be in constant pressure for developing the next generation "similar biologics" including "biobetters" through incremental innovation implying that such companies would have to resort to constant $R \& D$ to move into introducing products of better characteristics to remain competitive. "Biobetters" are biosimilar products that seek superiority in one or several aspects of their clinical profile over the "biosimilar" products and therefore from regulatory point of view would require complying with additional regulatory pathways for approval and use. When "similar biologics" or "biobetters" are introduced, it implies that there would be cost savings to the society and that the competition shall be more severe when more complex biological products get introduced through such options requiring to invest more in technology as well as in R\&D, thereby considerably eroding the cost advantage. The future directions in the development of "similar biologics" for more complex molecules and technologies would be more complex and are yet not fully clear (37).

The cost of treatment using biologics like "reference products" in the US has been estimated to be US\$ 45 per day or US\$ 16425 per year compared to the treatment cost of patients with traditional pharmaceuticals at US\$ 2 per day or US\$ 730 per year depicting more than 20 times the treatment cost using biologicals(38).

From this information, it is clear that even in US, the treatment cost using branded biologic products is very high and would be unaffordable by many kinds of patients living in different economic situations and conditions. The high cost of "inventor's biologics" has become an important issue therefore in USA as well as all over the world in the battle of containing the ever-increasing healthcare costs.

In the USA, the country enacted in March 2010 its Biologics Price Committee and Innovation Act of 2009 (BPCIA) as an endeavour to provide affordable care to its people through its Patient Protection and Affordable Care Act (popularly known as Obamacare) in order to authorize approval of biosimilar products by USFDA. The approval pathway was defined under section 351(k) of the US Public Health Service Act where applicants for "similar biologics" are to demonstrate that the products are safe, pure and potent for the approved conditions of use as of the originator products. Following the enactment of the approval pathway, the cost saving potential from the use of "similar biologics" in USA is being worked upon by various agencies, even though during the time of writing this article only four "similar biologics" namely Zarxio (GCSF/Filgrastim) of Sandoz; Inflectra (Infliximab) manufactured by Celltrion Inc (and to be marketed by Pfizer); Erelzi (Etanercept) of Sandoz (a Novartis company); and Amjevita (Adalimumab) of Amgen Inc were approved by USFDA for use in the country(39). It has been predicted that use of "similar biologics" will lead to a reduction (40) in US\$ 44.2 billion (range US\$ 13-66 billion under various assumptions) in direct spending on biologic drugs in USA from 2014 to 2024, which amount is considered substantial. US therefore shall have profound interest in the introduction of "similar biologics" in their country.

The new treatment options especially of certain chronic diseases utilizing biologic medicines have brought considerable hope of increasing the quality of lives of patients even though the treatment cost remains high. During the last three decades about 80 biologic molecules produced by recombinant DNA technology have been launched globally to bring in new treatment options for life threatening chronic diseases. These include about 30 therapeutic proteins and another 50 monoclonal antibody-based products. "Similar biologics" medicines are subsets of the biologic medicines. Presently though the share of biologic medicines by value of the global market of pharmaceuticals is low, projections have been made that this sector will account for up to $28 \%$ by value of all pharmaceuticals used globally. It is also projected that global biologic medicine share by 2020 would exceed US $\$ 390$ billion. It has also 
been calculated that the cumulative potential saving to the healthcare cost in selected European markets and the US market as a result of using "similar biologics" may be above Euro 50 billion in aggregate over the next 5 years up to 2020 and may even be as much as Euro 100 billion (41) if there are changes in treatment options with greater choice for "similar biologics" made by the payers, physicians and the patients. These figures are indicators of the potentials of "similar biologics" in the near future. In the present day situation of constrained budgetary environment of most actors, it is anticipated that the global community will move towards utilizing the maximum potential emanating from the use of "similar biologics".

It is relevant to mention that while the phenomenal technological progress in fulfilling the unmet needs of humankind shall bring in more comforts in different facets of human life, some of these would also be reasons for developing and spreading illness in humans. Some illness will emanate from the enforced increased sedentary habits in human, many others shall evolve from the transformation of infective living entities especially some microbes and some others would evolve from induction of systemic defects from continuous exposure to electromagnetic radiations. There would therefore be greater urgency to develop newer medicines to treat illness where there are anticipated to be substantial unmet needs. The developments shall certainly be increasingly challenging and the researcher shall have to understand more of the biological basis of causation and progression of illness. The researchers in biopharmaceutical sector shall therefore be engaged in coming up with newer biological substances to intervene on the cause of such illness and these efforts shall foster innovation. The development of innovation biologicals would be expensive and therefore the newer products shall continue to be expensive. The manufacturers of "similar biologics" would have to wait to introduce such products from their manufacturing facilities till the IPR expires. In the meantime however, the "similar biologics" companies would have to materially upgrade their R\&D efforts to understand profoundly how such novel products work and how such products can be made to maintain physico-chemically a stable status and biologically in active form for long periods after manufacture. If "similar biologics" companies upgrade their research capabilities to profoundly advanced stages, then only such companies shall be able to reap more benefits from newer biological products after the expiry of IPR on them.

\section{PRESENT DOMINANT MARKETS \&TECHNOLOGICAL ASPECTS OF "SIMILAR BIOLOGICS"}

The most dominant markets of novel biopharmaceuticals including "similar biologics" as also the technologies required to steward these products forward in order of dominance are concentrated in North America (USA \& Canada), Western European countries (especially Germany, UK, France, Spain and Italy), China, Japan, India and South Korea. Some South East Asian countries, the whole of South America, Australia, Russia \& CIS countries are dormant at the moment but hold potential for faster growth in "similar biologics". The need for "similar biologics" in African countries is rising very fast because of faster increase in the incidence of chronic diseases and cancer in certain regions. Because of the impact of several other factors such as rise in the population of middle class, demanding more of upto-date treatment of chronic disease, increase in the infrastructure of medical services providers, more skills gained by the medical profession to treat complicated disease conditions, the introduction of some "similar biologics" resulting in reduction of prices of treatment costs, the growth of markets have been more in regions like China and India followed by North America, Western Europe, South America and South East Asian countries(42). While planning for the setting up of infrastructure for the manufacture of "similar biologics", these aspects of markets are to be kept in view.

In "similar biologics" manufacture, the titers obtained for the products as measured in terms of grams of target proteins(active biological ingredients) per unit volume of the bioreactor, the time taken for reaching the optimum titers measured in time from the start of cell culture process in the bioreactors, the recovery of "similar biologics" measured as the percentage of purified product obtained from the total mass of the active substance in the bioreactor at the point of harvesting a batch are the key measures that determine the operational efficiencies and cost of production. While the "similar biologics" products are to have quality traits not less than the quality traits of the reference products, the manufacturers are on pressure from the governments, the patients and the society to supply such products at most optimum rational costs. There is therefore an unstinted pressure on the manufacturers to have maximum manufacturing efficiencies so as to enable the sale of their products at most competitive prices. 


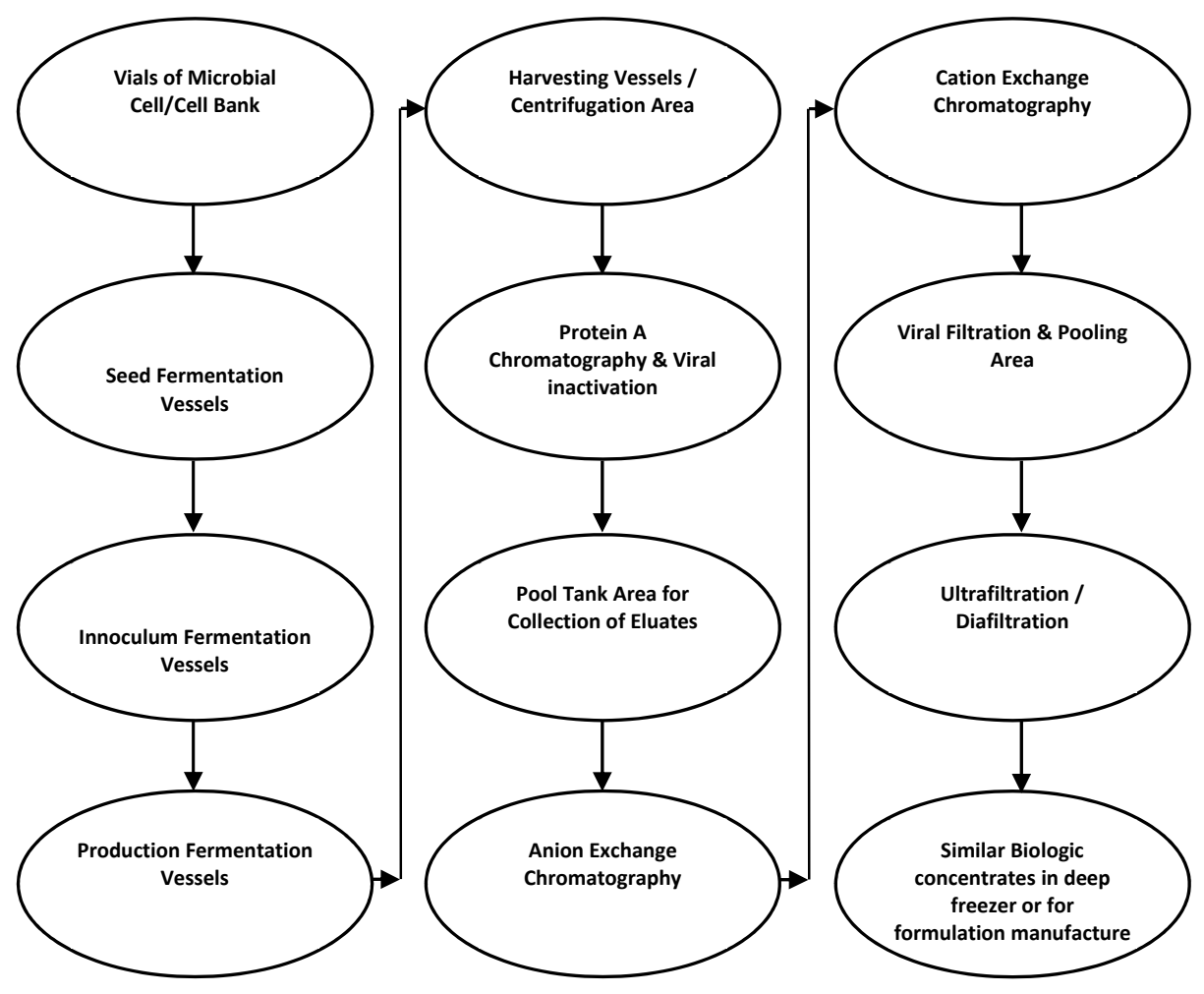

(Similar Biologic concentrates $=$ rDNA proteins including monoclonal antibody)

Figure 1. General Flow sheet for manufacture of "Similar Biologics"

In order to understand the stages where technological inputs profoundly determine the manufacturing cost, the general manufacturing steps need to be assessed. The above flow sheet (Figure 1) depicts schematically, the major steps involved in the manufacture of "similar biologics".

Escherichia coli (E.coli) cells are used for the manufacture of a few "similar biologics" which are not glycosilated; these include production of insulin, somatropin, antibody fragments such as Fabs etc. Cell lines of Saccharomyces cerevisiae and Pichia pastoris have also emerged (43) as promising microbes for producing certain cytokines and monoclonal antibodies. Most other products are manufactured using mammalian cells. Only a few cell lines such as Chinese Hamster Ovary (CHO), NS0 murine myeloma cells, PER.C6 human cells and certain others have been used for producing monoclonal antibodies (44).In order to ensure high productivity with profound attributes towards quality, the selection of right quality of cell lines is very important and critical. Among the mammalian cells, the $\mathrm{CHO}$ cell lines have rapid growth characteristics, high expression of target protein and can be adapted for growth in chemically defined media, thereby minimizing the chances of batch to batch variations in product qualities. Because of these attributes, $\mathrm{CHO}$ cell lines are preferred mammalian cells for biologics and "similar biologics" manufacture. While developing or for making a purchase decision of technologies, the selection of well established and well characterized cell line based technologies make a judicious and intelligent choice.

Out of some 174 recombinant proteins and antibodies currently approved in US or EU, 76 numbers of products are manufactured in microbial production system mainly in E.coli and yeast; 91 products are manufactured in mammalian cell lines of which 60 are made in $\mathrm{CHO} ; 4$ products are made in insect cells; 2 in transgenic animals, one each in goat and rabbit; and 1 product made in carrot cell culture (45).

Most of the older production facilities are based on establishment of stainless steel (SS-316) bioreactors equipped with pre- and post harvesting facilities. Such bioreactors are usually established in the range of capacities of 1 kilolitre to 50 kilolitres but closer range is between 2 to 25 kilolitres. The production is usually carried out on fed-batch culture mode as also continuous perfusion mode (46-48). 
The outputs from the production of bioreactors in fed-batch mode usually limit the overall production capacity. Presently, gross productivity in terms of titers in the bioreactor are in the range of 1-5 gm/L in 10-14 days fermentation time with some companies achieving $10-13 \mathrm{gm} / \mathrm{L}$ on extended duration of culturing. Usually a titer of more than $3 \mathrm{gm} / \mathrm{L}$ is considered as average titer for the industry engaged in the production of biologics. Various percentages of recovery of the biologics have been reported in the literature with high figures around or above $80 \%$ and the low figures of $65-70 \%$. However, the industry average for products manufactured through mammalian expression system including monoclonal antibodies is usually low and can be considered at $70 \%$ rather than $80 \%$. The product recovery time is typically not more than 2 days. The titer, the yield and the processing time vary from product to product but usually are within the range indicated above. Using these data $(45,49)$, on a continuous working basis with reasonable downtime for routine and annual scheduled maintenance, the productivities at $70 \%$ recovery on attainment of a titer of $3 \mathrm{gm} / \mathrm{L}$ in the production fermenter in 12 days, the per litre productivity of installed fermenter volume at $80 \%$ loading would work out to $3 \mathrm{gms} / \mathrm{L}$ X 0.8(fermentor loading) X 2.5(batches per month) X 12 (months in a year) X 0.7 (recovery efficiency)X0.95 (fermentation sterility) gms/L or $47.88 \mathrm{Kg}$ /kilolitre (KL). On attainment of average titer of 5 gms per litre, this figure would be 79.80 $\mathrm{Kg} / \mathrm{KL}$. Using a set of 4 numbers of $2 \mathrm{KL}$ production fermenters with matching pre and post fermentation operations, the annual production capacity is anticipated to be $383.04 \mathrm{Kgs} / \mathrm{Y}$, say 380 $\mathrm{Kgs} / \mathrm{Y}$ at $3 \mathrm{gm} / \mathrm{L}$ titer and $638.4 \mathrm{Kgs} / \mathrm{Y}$ say 640 $\mathrm{Kgs} / \mathrm{Y}$ at $5 \mathrm{gm} / \mathrm{L}$ titer respectively.

These figures can be used as benchmarks while installing local plants or negotiating for technology purchase. These would avoid going into the intricate aspects of technology assessment in the first round.

Several operators have resorted to perfusionculture mode of production where fresh media is continuously fed into bioreactors while growth inhibitory products are continuously removed. In such operations, cell densities of the mammalian cells increase considerably and may reach (50) levels of $3 \times 10^{7}$ to $1 \times 10^{8}$ cells per ml whereas in fed-batch system the levels are about $5 \times 10^{6}$ to 2.5 $\mathrm{X} 10^{7}$ cells per $\mathrm{ml}$. The size of the bioreactor is also substantially reduced in case of perfusion-culture mode of production. There are certain kinds of advantages however in fed-batch mode, which issues are not discussed here. Of late, another system of production is becoming popular where production appliances are made up of plastics and such systems are for one-time use. Such single- use systems(SUSs) are fast developing and replacing the conventional stainless-steel bioreactors as well as the piping and other pre and post fermentation processes; indeed in certain developed countries ,these technologies are becoming more popular. A large number of biopharmaceuticals are produced in SUSs in perfusion culture by a number of companies such as Bayer, Eli Lily, Genzyme, Janssen, Merck-Serono and Novartis (51).

The SUSs bioreactors and the upstream as well as the downstream SUSs are " disposables" manufactured from a varied range of plastic materials such as cellulose acetate (CA), polyvinyl chloride (PVC),ethylene vinyl acetate (EVA), polycarbonates(PC) synthesized from bisphenol-A and phosgene, polyethylene (PE) manufactured by polymerization of ethylene oxide, nylon type polyamides (PA), polyethersulfone (PESU) produced by the condensation of suitable bisphenols and bis(4-chlorophenyl)sulfones, polypropylene(PP) produced by polymerizing propylene oxide, polytetrafluorethylene (PTFE)etc. The SUSs products include a wide range from bioreactors, mixing vessels and filling systems, a wide range of filtration systems, pumps, centrifuges, chromatography systems, freeze \& thawing systems, isolators, tubing, connections, plugs, seals, transfer systems, sampling systems and a whole lot of work equipment.

The SUSs are becoming so versatile that these are being available for carrying out multiple types of unit operations in the upstream processing areas such as storage and transfer of solids and liquids, dissolution operations, filtration of mixtures, homogenisation of fluids where required, dispersal of droplets and gas bubbles and operations for transfer of materials to obtain phase interfaces. Equipment for use in the downstream operations such as dead-end sterile filtration, cross-flow filtration including ultrafiltration and diafiltration, functional filtration including membrane absorption such as affinity and ion exchanger processes as well as various kinds of chromatography in the small scale such as cation exchange, anion exchange, hydrophobic interaction chromatography and mixed-mode chromatography can be carried out. There is however, gap in the use of large scale chromatographic operations as well as in the availability of adequate spectra of sensor equipment. Other than these two areas, most SUSs can be comparable to SS-system. In other words, all the unit operations and unit processes that are 
required to be carried out using SS-system can also be carried out using SUSs. Thus, the equipment, system designs and components are holding the potential of taking over the processes and operations used in SS-system as more scientific developments take place in these areas (52).

In a new setup, SUSs have to contribute to equivalent, if not better, overall attributes compared to the overall performances achieved in fed-batch SS-systems. In the manufacture of biologicals, SUSs have to contribute to high patient safety of formulations on one hand and on the other side these would have to ensure prompt supply (systems and equipment) to the manufacturers. In eventual acceptance of SUSs, these should yield overall lower cost of production to be acceptable by entrepreneurs. The regulatory requirements for maintaining the quality of the products especially on the concerns from extractables and leachables have been evolving and the regulatory documents from US FDA, EMA, ISO, ICH, WHO etc. which provide guidance for maintenance of standards need to be complied with by the manufacturers and suppliers of SUSs. Fortunately, the present suppliers of SUSs are themselves conducting considerable in-house test to ensure compliance with regard to international and statutory guidelines. Many such companies are also certifying for compliance for robust regulatory package based on which biologic companies procuring them can proceed, thereby reducing the need to conduct tests for cleaning and validation which also results in lesser documentation needs. The use of SUSs result in saving in labour and materials for portions and parts of the process requirement for maintaining sterility of the bioreactors as well as the pre and post handling systems as the systems are supplied and guaranteed sterile. SUSs are sterilized by gamma radiation and therefore ensure total sterility. As a result of use of sterile equipment, there is considerable saving in the use of large volumes of high quality water (injection grade), chemicals and labour. These costs are unavoidable for SS bioreactor system. SUSs, also require lesser space for storage area. There are issues of requirement of larger quantities of waste management when SUSs are used. Disposal of such wastes in land filling or in recycling of plastics in other safe areas are controversial and also result in incurring costs by the users. Newer methods such as by burning and concomitantly generating steam and electricity can be explored to make the SUSs more economical (53).

Presently, the main limitations on the use of SUSs are high procurement cost, supply security and uncertainties in assuring absence of leachable and extractable from the plastics. All the SUSs require sterilization by gamma ray irradiation processes. Such facilities are not in place in many parts of the world. Besides, other limitations include small range of operable pressure range, limited flow rates, inadequacies in generating adequate centrifugal forces, working temperature range limitations, gas ( oxygen and carbon dioxide) stripping rates from systems where required. Further, employee training, quality assurance and standardization of production processes are other issues. Interestingly, these limitations are fast being addressed by the suppliers especially in the developed country regions.

The decision to go for SUSs for the manufacture of biologics and "similar biologics" instead of the long used and well established SS systems would depend upon the place and the country where such systems are being installed, the products to be manufactured and the processes to be chosen. This shall also depend on the long term business objectives of the organization. To obtain fully compliant plastics from proven suppliers having established reputations without having to fetch frequent change notices from the vendors are issues a manufacturer has to consider. There are several other issues like continuous and timely availability of materials, components and system design requirements of SUSs, on which unreliability of supply can seriously jeopardize production schedule. In many countries on overall consideration, the use of SS-system would continue to prevail for another one decade over the use of SUSs especially in regions where significant growth in demand for "similar biologics" is getting generated in local emerging markets such as India, China, South East Asian countries and Southern American countries, where the local governments are also promoting the establishment of "local production" infrastructure.

\section{NEW REGULATORY FRAMEWORKS EMERGING WORLDWIDE FOR "SIMILAR BIOLOGICS"}

Worldwide, because of emerging large and growing market of "similar biologics" emanating from the benefits derivable from their use for containing certain chronic diseases and conditions, almost every country is taking steps to ensure the availability of such products within their territory either by local manufacture or by imports by easing the procedures for imports. The regulatory frameworks of all major countries are fast emerging to provide speedy structured approvals so as to enable the consumers to get the benefits of 
use of such medicines within their regions. There is however considerable resistance from certain countries particularly from the US regulators to formally approve the production of "similar biologics" from new "similar biologics" manufacturers for use in their territory. The main reasons appear to be to ensure that the products approved provide to the patients the highest standards of quality, safely and efficacy comparable to the inventor's reference product. Perhaps there are doubts that approval of "similar biologics" in different countries does not go through the same stringent processes of data generation and data scrutiny, a situation which has not been rationalized and standardized globally.

\section{SIMILAR BIOLOGICS APPROVAL PROCEDURES: COUNTRY-SPECIFIC DEVELOPMENTS}

The competitive pressure as well as the market for "similar biologics" varies from country to country. World over, there are "regulated markets" as well as "semi-regulated markets" for "similar biologics". The highly developed countries such as USA, Canada among the western countries, the whole of European countries including Norway, Netherlands, UK, Germany, France, Sweden, Switzerland, Belgium, Italy etc and Japan among the Asian countries have strong policies for introduction of "similar biologics" in their territories. The Australian guidelines for "similar biologics" are also similar to those as found in the highly developed regions and were based on the EU guidelines.

Among the Asian countries, India, China and South Korea have a large number of "similar biologics" introduced in their territories. The ASEAN countries are active through their Association for the development of a common technical dossier though the guidelines have not yet been finalized and adopted for biologicals and "similar biologics" in all the ASEAN Member States. Some ASEAN countries have in the meantime come out with their "similar biologics" policies.

Among the South American countries, Brazil, Bolivia, Chile, Colombia, Ecuador, Mexico, Paraguay, Peru and Venezuela are countries that have approved one or more "similar biologics" or "biosimilars" for use in their territories.

Among the nine Common Wealth of Independent States (CIS), the main market in terms of consumption is anticipated to be Russia (2015 population was 146.27 million) followed by Uzbekistan (2015 population was 31.025 million), Kazakhstan (2015 population was 17.417 million),
Belarus (9.475 million in 2015) and Azerbaijan (9.356 million in 2015); the combined population of the five countries was more than $91 \%$ of the total population of the region. In terms of per capita GDP (2012), Russia was on the top followed by Kazakhstan, Belarus, Azerbaijan and Uzbekistan (54). In all these CIS countries, the procedures for introduction of "similar biologics" are gradually evolving.

In all countries, the regulations for approval of "similar biologics" are based on proving the comparability of the products to an already approved reference product. The comparability measurements are defined in terms of quality, nonclinical physico-chemical identification and evaluation of products and processes and finally a clinical evaluation. The "similar biologics" are biotechnologically manufactured gene expression products which are essentially recombinant protein products. In all the countries, the abbreviated pathway package requires full quality assessment of the products by physico-chemical methods using most sophisticated instruments. There is however a relaxation in the generation of comparative clinical studies which situation varies from country to country. A minimum comparative clinical study is required with comparators of each clinical indication. In terms of quality studies, extensive physico-chemical experimentations are required to demonstrate physico-chemical properties, biological activities, immunological properties, impurities profile, purity characteristics and stability data. All the analytical techniques are to be the state-of-the-art techniques and technologies that are capable of detecting small differences in quality attributes. The impact of the observed differences of the "similar biologics" with the reference drug is to be assessed based on which the clinical studies are designed. Each country decides the acceptability criteria in the dossier to be prepared and submitted. All nonclinical study data are designed to be comparative in nature. The reference product in every country is considered to be a drug that has already been approved by a regulatory authority on the basis of submission of full regulatory dossier. Always the reference products are used for demonstrating the comparability of "similar biologics" with reference to quality, non-clinical and clinical studies. The "similar biologics" are converted into dosage forms, strength and root of administration, which essentially have to be the same as that of the reference products. In many cases where the reference product is not available in the local market, the reference products can then be procured from another country based on full 
information of approval of reference product. For conducting the clinical studies, pharmacokinetic as well as pharmacodynamic data generation are mandatory. Clinical studies are conducted in a comparable manner using the reference product. Even though a similar biologic product shows adequate comparability to the reference product for one indication, it is usually not allowed to extend the approval of similar biologics to all other indications of the reference product without generating clinical data. In some counties however exceptions are made on the basis of the argument that the mechanism of action for the "similar biologics" shall be the same as that of the reference product. Usually in such situations for extrapolation of indication, a case by case analysis and approval has been considered to be more rational. The WHO Guidelines (55) on evaluation of "similar biologics" is comprehensive and is based on a comparative study of the "similar biologic" product with the previously licensed reference product comparing the quality, safety and efficacy. While developing Guidelines for approving "similar biologics", many countries have used the WHO Guidelines as the basis in formulating their authorization document.

The major country-wise regulatory framework as well as the approved "similar biologics" are provided below.

\section{USA}

The US Government enacted its Patient Protection and Affordable Care Act (Affordable Care Act) on March 23, 2010 amending its Public Health Service Act (PHS Act), thereby creating an abbreviated license pathway for biologics that can be demonstrated to be "biosimilar" to or "interchangeable" with FDA's licensed biological product. The developers of "biosimilar products" seeking license for manufacturing such products, also identified as the biologics license application (BLA) holders, required clarification on certain questions like the type and extent of data requirements for proving what "biosimilarity" and "interchangibility" would mean in reference to the inventor's US FDA approved biologics; how applications are to be submitted to US FDA for obtaining approval; and issues relating to whether there existed unexpired orphan exclusivity for any indication for which the reference product is licensed. The US FDA subsequently therefore, in April 2015 published its "Guidance for Industry" for introducing "biosimilars" in the country (56)for easing and bringing in more clarity. Presently, four "biosimilar" products in four brand names have been approved by the country as per information below in Table 1.

\section{CANADA}

Health Canada is the federal regulatory authority to provide authorization for the manufacture of "similar biologics" in the country. Such products are termed as "subsequent entry biologicals" (SEBs) in Canada. Authorization of sale of SEBs is based on demonstrated similarity to a previously approved biologic drug in the country. The Biologics and Generic Therapies Directorate (BGTD) of Canada is the regulator of biologic drug for human use, which provides regulatory oversight of such products with comprehensive reviews covering quality, safety and efficacy, lot release and on-site evaluation.

Table 1."Biosimilars" or "Similar Biologics" approved in USA

\begin{tabular}{|c|c|c|}
\hline $\begin{array}{c}\text { Common name/Generic name of } \\
\text { Similar Biologics Approved }\end{array}$ & $\begin{array}{c}\text { Name of the Company with } \\
\text { Brand Name }\end{array}$ & Indications for use \\
\hline G-CSF/Filgrastim-sndz & Sandoz- Zarxio(57-59) & $\begin{array}{l}\text { Stimulates proliferation and } \\
\text { differentiation of granulocytes }\end{array}$ \\
\hline Infliximab/Infliximab-dyyb & Celltrion- Inflectra $(60)$ & $\begin{array}{l}\text { To treat arthritis, psoriasis, } \\
\text { ulcerative colitis and Crohn's } \\
\text { disease }\end{array}$ \\
\hline Etanercept/Etanercept-szzs & Sandoz-Erelzi (61) & $\begin{array}{l}\text { To treat axial spondyloarthritis, } \\
\text { psoriatic arthritis, plaque psoriasis } \\
\text { and rheumatoid arthritis }\end{array}$ \\
\hline Adalimumab/Adalimumab-atto & Amgen-Amjevita(62) & $\begin{array}{l}\text { To treat rheumatoid arthritis, } \\
\text { psoriatic arthritis, ankylosing } \\
\text { spondylitis, Crohn's disease, } \\
\text { ulcerative colitis }\end{array}$ \\
\hline
\end{tabular}


A sponsor has to name the reference biologic drug authorized in Canada to which the SEB will be subsequent. Sponsors of SEBs consult the BGTD for regulatory guidance at any stage of development. Information for submission requirement for SEBs is on the internet (63). Presently, four "similar biologics" in five brand names are approved in Canada as provided in Table 2(64).

\section{EUROPEAN UNION}

In EU, the market authorization for "similar biologics" is provided by the European medicinal Agency (EMA). These products are generally categorized as "similar biological medicinal products" by the EU. The EU had been active in creating the legal framework for approving "similar biologics" from 2003 and came out with a draft in April 2005 which draft became effective from 01/06/2006(70). This framework was for approval of "similar biologics" by an abbreviated registration process. Later, the guidelines had undergone changes and as of date the latest guidelines came into effect from 01/06/2015(71). These guidelines recommend a step wise conduct of non-clinical and clinical studies to generate data to show that the product for which approval is sought is similar to the reference biological product. Up to present time, 23 "similar biologics" had been approved by the EU, of which two were withdrawn by the applicants; these include one brand of filgrastim, withdrawn in April 2011 and the other for Somatropin withdrawn in May 2012. The "similar biologics" approved in EU fall under the category of erythropoiesis stimulating substances, substances used to stimulate the proliferation and differentiation of granulocytes, follicle stimulating proteins, growth hormones, fast acting insulin and monoclonal antibodies. While the EMA authorizes marketing of "similar biologics", every country in addition retains control over substitution policies, i.e., whether "similar biologics" can be used interchangeably with the reference product. Presently, 24 brands of "similar biologics" have been approved in EU as provided in Table 3(72).

Table 2."Subsequent Entry Biologics" or "Similar Biologics" approved in Canada

\begin{tabular}{lll}
\hline \multicolumn{1}{c}{$\begin{array}{c}\text { Common name/Generic of Similar } \\
\text { Biologics Approved }\end{array}$} & $\begin{array}{c}\text { Name of the Company with } \\
\text { Brand Name }\end{array}$ & \multicolumn{1}{c}{ Indications for use } \\
\hline Somatropin & Sandoz-Omnitrope(65) & To treat growth hormone deficiency \\
Infliximab & $\begin{array}{l}\text { Hospira- Inflectra(66) } \\
\text { Celltrion- Remsima(67) }\end{array}$ & $\begin{array}{l}\text { Various arthritis, psoriasis, ulcerative } \\
\text { colitis and Crohn's disease }\end{array}$ \\
Filgrastim/ G-CSF & Apotex- Grastofil(68) & $\begin{array}{l}\text { Stimulates proliferation and } \\
\text { differentiation of granulocytes; used } \\
\text { in treatment of neutropenia }\end{array}$ \\
Etanercept & Merck Canada- Brenzys(69) & $\begin{array}{l}\text { To treat spondyloarthritis, psoriatic } \\
\text { arthritis, plaque psoriasis and } \\
\text { rheumatoid arthritis }\end{array}$ \\
\hline
\end{tabular}

Table 3: "Similar Biologics" approved in European Union

\begin{tabular}{lll}
\hline $\begin{array}{c}\text { Common name/Generic } \\
\text { of Similar Biologics } \\
\text { Approved }\end{array}$ & Name of the Company with Brand Name & Indications for use \\
\hline Insulin glargine & Eli Lilly/Boehringer Ingelheim -Abasaglar(73) & Long acting insulin to treat diabetes
\end{tabular}

Epoetin alfa

Epoetin zeta

Hospira- Retacrit(77)

STADA R\&D- Silapo(78)

Sandoz- Binocrit(75)
Medice Arzneimittel Pütter - Abseamed(74)

Hexal- Epoetin alfa Hexal(76)

G-CSF/Filgrastim

Accord Healthcare- Accofil(79)
To treat Anaemia, cancer and chronic kidney failure condition

To treat anaemia, autologous blood transfusion, cancer and chronic kidney failure 


\begin{tabular}{|c|c|c|}
\hline & $\begin{array}{l}\text { CT Arzneimittel- Biograstim(80) } \\
\text { Hexal- Filgrastim Hexal(81) } \\
\text { Apotex- Grastofil( } 82) \\
\text { Hospira- Nivestim(83) } \\
\text { Ratiopharm- Ratiograstim( } 84) \\
\text { Teva Generics- Tevagrastim(85) } \\
\text { Sandoz- Zarzio(86) }\end{array}$ & $\begin{array}{l}\text { Stimulates proliferation and } \\
\text { differentiation of granulocytes }\end{array}$ \\
\hline Infliximab & $\begin{array}{l}\text { Samsung Bioepis- Flixabi(87) } \\
\text { Hospira- Inflectra( } 88) \\
\text { Celltrion- Remsima(89) }\end{array}$ & $\begin{array}{l}\text { Various arthritis, psoriasis, ulcerative } \\
\text { colitis and Crohn's disease }\end{array}$ \\
\hline Etanercept & Samsung Bioepis - Benepali(90) & $\begin{array}{l}\text { To treat axial spondyloarthritis, } \\
\text { psoriatic arthritis, plaque psoriasis and } \\
\text { aheumatoid arthritis }\end{array}$ \\
\hline Follitropin alfa & $\begin{array}{l}\text { Finox Biotech- Bemfola }(91) \\
\text { Teva Pharma- Ovaleap }(92)\end{array}$ & To treat anovulation disorder \\
\hline Somatropin & $\begin{array}{l}\text { Sandoz- Omnitrope(93) } \\
\text { BioPartners- Valtropin(94) }\end{array}$ & $\begin{array}{l}\text { To treat growth hormone deficiency } \\
\text { disorder }\end{array}$ \\
\hline Teriparatide & $\begin{array}{l}\text { STADA Arzmeimittel- Movymia(95) } \\
\text { Gedeon Richter-Terrosa(96) }\end{array}$ & To treat some forms of osteoporosis \\
\hline
\end{tabular}

\section{JAPAN}

In Japan, the Ministry of Health, Labour and Welfare (MHLW) is the regulatory body which is responsible for the evaluation of "similar biologics" in the country. A similar biologic product is designated as a "follow on biological medicinal product" (FOBMP) in Japan(97). It is also termed as "biosimilar product" in several other documents including official documents of the country (98). The Pharmaceuticals and Medicinal Devices Agency (PMDA) of Japan is the regulatory agency that works together with MHLW. The Office of Biologicals of PMDA guides the applicants for "similar biologics" concerning data generation and information submission. The Evaluation and Licensing
Division of MHLW through their notification no. 0304007 dated March 04, 2009 issued the guidelines (97) for "similar biologics". The guidelines aim at presenting requirements which are considered for the development of FOBMPs. The guidelines are similar to the EU guidelines and require the applicants to demonstrate that the quality attributes are highly similar to those of the reference biological products. Up to the present time, nine brands of five different kinds of therapeutic-area-specific "similar biologics" have been approved in Japan as per details given in Table 4(99).

Table 4: "Similar Biologics" approved in Japan

\begin{tabular}{llc}
\hline $\begin{array}{c}\text { Common name/Generic of } \\
\text { Similar Biologics } \\
\text { Approved }\end{array}$ & Name of the Company with Brand Name & Indications for use \\
\hline $\begin{array}{l}\text { Somatropin } \\
\text { Epoetin alfa }\end{array}$ & Sandoz- Somatropin BS & $\begin{array}{c}\text { To treat growth } \\
\text { hormone deficiency }\end{array}$ \\
& JCR Pharmaceuticals- Epoetin alfa BS & $\begin{array}{l}\text { To treat anaemia, } \\
\text { cancer and chronic } \\
\text { tailure } \\
\text { kidney } \\
\text { conditions }\end{array}$ \\
Darbepoetin alfa & Kyowa Hakko Kirin- Nesp & $\begin{array}{l}\text { To treat anemia, } \\
\text { chronic kidney failure } \\
\text { and various cancer. }\end{array}$ \\
\hline
\end{tabular}




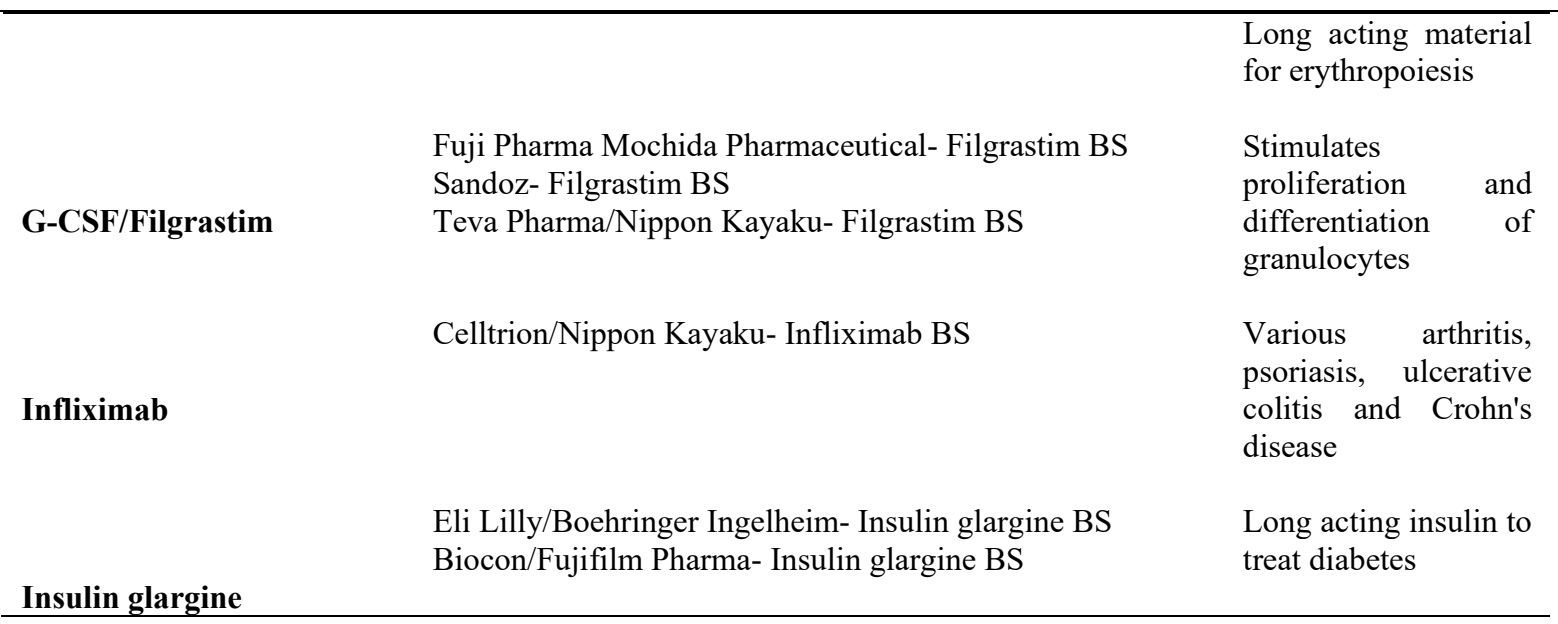

\section{LATIN AMERICA}

All governments are eager to create conditions within their territories to enable the use of "similar biologics" because of increasing financial pressures emanating from the use of reference biologicals. Out of the presently existing 33 sovereign states and 15 dependencies territories, the countries with population of more than 10 million are Brazil, Mexico, Columbia, Argentina, Peru, Venezuela, Chile, Guatemala, Ecuador, Cuba, Bolivia, Haiti and Dominican Republic and their combined population was around 588 million, representing more than $91 \%$ of the total Latin American population(100).

Mexico is situated in North America. The Central America houses Belize, Costa Rica, El Salvador, Guatemala, Honduras, Nicaragua and Panama. The South America comprises Argentina, Bolivia, Brazil, Chile, Columbia, Ecuador, French Guinea, Guyana, Paraguay, Peru, Surinam, Uruguay, and Venezuela. The Caribbean countries are another large number of medium and small countries including Cuba, the Dominican Republic, Haiti, Jamaica, Bahamas and Trinidad \& Tobago. South America is ethnically and geographically diverse. The first language of most of these countries is Spanish while the Brazilians speak Portuguese. The demographic factors as also the socio-economic conditions are factors distinguishing people from one region to the other. The healthcare business is dominated by the multinational companies from Europe and US. The pharmaceutical sales in Latin American countries was USD 73 billion in 2012, which was around 8\% of the global pharmaceutical sales(101). Brazil, Mexico, Argentina and Columbia are the top four economic and pharmaceutical powers in the region.
In this paper, the policies adopted by major Latin American states whose present population was more than 10 million were looked at. The regulations for the approval of "similar biologics" vary considerably among the countries and many have not yet introduced their guidelines. However most of the counties which have introduced such guidelines have developed theirs mostly taking into consideration the WHO guidelines. Interestingly, in some countries products similar to the reference biological products were already approved without exhaustive clinical testing having been performed. Such steps were taken obviously with a view to make less costly "similar biologics" available to its people by encouraging local manufacture. In Brazil for example where Agência Nacional de Vigilância Sanitária (ANVISA) working under the Ministry of Health of the Brazilian government, is responsible for drug registration and licensing to clients has come out with guidelines on "similar biologics" entitled "Resolução RDC n 55 de 16 de dezembro de 2010. Dispões sobre o registro de produtos biológicos novos e produtos biológicos e da outras providências" (Resolution no. 55/2010) dated December 16, 2010 elaborating two regulatorypathways (102-103) for "similar biologics". One regulatory pathway is based on a comparative evaluation of the similar biologic with the reference product while the other one is an individual development pathway requiring a reduced dossier where applicants need to generate complete data on quality issues but it does not require these to be comparable. The Mexican Congress passed and published on $11^{\text {th }}$ June 2009 by incorporating Article 222 in their General Health Law to deal with biotechnological medications. Subsequently on $19^{\text {th }}$ October 2011, the Regulation of Health Sector products were 
amended by a decree (DOF-19-10-2011) and by another decree on $16^{\text {th }}$ June 2012 relating to biocomparable biotechnological medications (DOF-19-16-2012). These decrees are the regulatory instruments related to biotechnological products in Mexico(104). Columbia from its Ministry of Health and Social Protection, known locally as the Ministerio de Salud y Protección Social de Colombia, released its guidelines on "similar biologics" in January 2013. The guidelines are based on generation of information on the 'comparability pathway' matching up the performance with the reference biologic product. The Columbian Instituto Nacional de Vigilancia de Medicamentos y Alimentos (INVIMA) which is the institute for Drug and Food Surveillance of Columbia, provides the authorization for "similar biologics" for use in the country. On September 18, 2014 the President of Columbia signed a decree defining the ways and the standards that the country would require to register "similar biologics" in Columbia. According to this decree, an "abbreviated route" or "fast track route" for the registration of "similar biologics" will be used utilizing the concept of "comparability" and will ease(105) faster introduction of "similar biologics". In Argentina, the drug registration is authorized by La Administración Nacional de Medicamentos, Alimentos y Tecnología (ANMAT). This organization regulates drugs registration by Decree 150/1992 and posterior modifications(106). The draft guideline for "similar biologics" designated as similar biological medicines or medicamento biologico similar was issued in July 2008 and were subsequently notified on $14^{\text {th }}$ October 2011 (Decree 7075)(107) and $14^{\text {th }}$ November 2011 (Decree 7729)(108). The guidelines are an abbreviated licensing pathway for similar biologics and are essentially based on the EU model. The Government of Peru published their guidelines on similar biologics on $31^{\text {st }}$ July 2011 and the guidelines came into effect on $9^{\text {th }}$ November 2012(109). The guidelines have provisions for an abbreviated licensing pathway for similar biologics through "similarity analysis" and have ingredients of the guidelines of the WHO(55).

The guidelines for the registration of "similar biologics" were issued by the Venezuelan Instituto Nacional de Higiene Rafael Rangel (INHRR) on $12^{\text {th }}$ June 2012(110). The guidelines are based on generation of information on "similarity pathway" in terms of quality, safety and efficacy to the reference biopharmaceutical product. Extrapolation for use of indications is not allowed; for this, separate information is to be generated.
The draft guidance for the evaluation of "similar biologics" was published by Chile's El Departamento Agencia Nacional de Medicamentos (ANAMED) in October 2011(111). The country is yet evolving in the setting up of more comprehensive guidelines for the complex "similar biologics". The Ministry of Public Health and Social Assistance of the Government of Guatemala known locally as The Ministerio de Salud Pública y Asistencia Social (MSPAS) had announced its policies for "similar biologics" on $30^{\text {th }}$ October 2010 through pronouncement of "Technical standard 67-2010" which was later revised(112) on $5^{\text {th }}$ January 2015. Utilizing these standards the country takes a decision on the use of "similar biologics" in their territory. For Ecuador, the similar biologic guidelines (113) of 2013 take into cognizance the approval procedures. Cuba released (114) its draft guidelines for meeting the requirements for marketing authorization for the approval of non-biological products in October 2010. These guidelines are essentially based on the biosimilar guidelines of WHO (55). Regulations for the faster introduction of "similar biologics" are gradually evolving in several other Latin American countries. A study made some time back on the status of regulations in Latin American countries indicate that many countries have not yet come out with their abbreviated guidelines (115).

The different kinds of "similar biologics" that have been approved in certain Latin American countries are provided as per details given in Table 5.

\section{AUSTRALIA}

The legal framework for approving and regulating medicines in Australia is through their Therapeutic Goods Act 1989, administered by the Therapeutic Goods Administration (TGA) through which the Australian government regulates use of medicine in their country including biologicals. The "similar biologics" are evaluated based on demonstration of comparability in safety, purity and potency with the reference biologics.

The guiding principles are based on applying a risk management approach which is designed to ensure standards of therapeutic goods supplied in Australia to meet the standards of quality, safety and efficacy. The safety assessment is based on scientific and clinical expertise to decision making. The regulation of biosimilar medicines was announced in August 2008 and the guidelines are founded on similar biologic guidelines of the EU. The revised and latest version is Version 2.0 which is effective from 17/12/2015(125). The first similar 
biologic product approved in Australia was epoetin lamda in January 2010.
Presently, 13 numbers of similar biologic products in 18 different brands have been approved in the country as per details given in Table 6 .

Table 5: "Similar Biologics" approved in Latin America

\begin{tabular}{|c|c|c|}
\hline $\begin{array}{c}\text { Common } \\
\text { name/Generic of } \\
\text { Similar Biologics } \\
\text { Approved }\end{array}$ & Name of the Company with Brand Name & Indications for use \\
\hline \multicolumn{3}{|l|}{ BRAZIL } \\
\hline G-CSF/Filgrastim & Eurofarma Laboratórios- Fiprima(116-117) & $\begin{array}{l}\text { Stimulates proliferation and } \\
\text { differentiation of granulocytes }\end{array}$ \\
\hline Infliximab & Celltrion/Hospira- Remsima(118) & $\begin{array}{l}\text { Various arthritis, psoriasis, ulcerative } \\
\text { colitis and Crohn's disease }\end{array}$ \\
\hline \multicolumn{3}{|l|}{ BOLIVIA } \\
\hline Rituximab & $\begin{array}{l}\text { Dr. Reddy’s Laboratories- } \\
\text { Reditux/Tidecron(119) }\end{array}$ & $\begin{array}{l}\text { Non-Hodgkin lymphoma, leukaemia, } \\
\text { rheumatoid arthritis }\end{array}$ \\
\hline $\begin{array}{l}\text { COLUMBIA } \\
\text { Etanercept }\end{array}$ & Shanghai CP Goujian- Etanar(120) & $\begin{array}{l}\text { To treat spondyloarthritis, psoriatic } \\
\text { arthritis, plaque psoriasis and } \\
\text { rheumatoid arthritis }\end{array}$ \\
\hline Infliximab & Celltrion/ Hospira- Remsima(121) & $\begin{array}{l}\text { Various arthritis, psoriasis, ulcerative } \\
\text { colitis and Crohn's disease }\end{array}$ \\
\hline \multicolumn{3}{|l|}{ ARGENTINA } \\
\hline Rituximab & Elea- Novex(122) & $\begin{array}{llr}\text { To treat } & \text { chronic lymphocytic } \\
\text { leukemia } & \text { and } & \text { non-Hodgkin's } \\
\text { lymphoma } & & \end{array}$ \\
\hline \multicolumn{3}{|l|}{ CUBA } \\
\hline Human IFN & CIGB- Leuferon(123) & To treat viral infections and cancer \\
\hline $\begin{array}{l}\text { Leukocyte extract } \\
\text { termed transfer factor }\end{array}$ & CIGB- Hebertrans(123) & $\begin{array}{l}\text { To treat immune deficiencies, herpes } \\
\text { and ataxia telangiectasia }\end{array}$ \\
\hline $\begin{array}{l}\text { Recombinant IFN- } \\
\text { alpha } 2 \text { b }\end{array}$ & CIGB- Heberon alfa R(123) & To treat hepatitis $\mathrm{C}$ and cancer \\
\hline $\begin{array}{l}\text { Recombinant EGF } \\
\text { (produced in } \\
\text { Escherichia coli) }\end{array}$ & CIGB- Hebermin(123) & To treat burns and diabetic ulcers \\
\hline Recombinant HbsAg & CIGB- Heberbiovac HB(123) & HepatitisB vaccine \\
\hline $\begin{array}{l}\text { Recombinant } \\
\text { streptokinase }\end{array}$ & CIGB- Heberkinasa(123) & $\begin{array}{l}\text { Cardiovascular disease treatment, } \\
\text { dissolution of thrombus }\end{array}$ \\
\hline $\begin{array}{l}\text { Recombinant } \mathrm{Bm} 86 \\
\text { protein vaccine }\end{array}$ & CIGB- GAVAC(123) & $\begin{array}{l}\text { Cattle tick (Boophilus microplus) } \\
\text { control }\end{array}$ \\
\hline $\begin{array}{l}\text { Recombinant IFN- } \\
\text { gamma }\end{array}$ & CIGB- Heberon Gamma R(123) & $\begin{array}{l}\text { Juvenile rheumatoid arthritis } \\
\text { treatment }\end{array}$ \\
\hline $\begin{array}{l}\text { Recombinant vaccine } \\
\text { comprising HBsAg and } \\
\text { Hib }\end{array}$ & CIGB- Bivalent 'HB-Hib(123) & $\begin{array}{l}\text { Vaccine for hepatitis } \mathrm{B} \text {, pneumonia } \\
\text { and meningitis }\end{array}$ \\
\hline $\begin{array}{l}\text { Tetravalent (DPT-HB) } \\
\text { vaccine }\end{array}$ & CIGB- Trivac HB(123) & $\begin{array}{l}\text { Vaccine for diphtheria, tetanus, } \\
\text { whooping cough and hepatitis B }\end{array}$ \\
\hline
\end{tabular}




\begin{tabular}{lll}
\hline $\begin{array}{l}\text { Pentavalent (DPT- } \\
\text { HB+Hib) vaccine }\end{array}$ & CIGB-Heberpenta(123) & $\begin{array}{l}\text { As above plus vaccines for } \\
\text { influenzae } \\
\text { haemophilus } \\
\text { meningitis }\end{array}$ \\
$\begin{array}{l}\text { Recombinant IFN- } \\
\text { alpha2b and ribavirine }\end{array}$ & CIGB-Heberviron(123) & To treat hepatitis C \\
$\begin{array}{l}\text { Recombinant } \\
\text { granulocyte colony } \\
\text { stimulating factor }\end{array}$ & CIGB-Hebervital(123) & Treatment of leukopenia, neutropenia \\
$\begin{array}{l}\text { Recombinant } \\
\text { erythropoietin-alpha }\end{array}$ & CIGB- Heberitro(123) & \\
$\begin{array}{l}\text { Nimotuzumab } \\
\text { CIM- CIMAher(124) }\end{array}$ & $\begin{array}{l}\text { To treat anaemia, cancer and chronic } \\
\text { kidney failure conditions }\end{array}$ \\
& & $\begin{array}{l}\text { To treat head and neck cancer; binds } \\
\text { to the epidermal growth factor } \\
\text { receptor (EGFR) that controls cell } \\
\text { division }\end{array}$ \\
\hline
\end{tabular}

Table 6: "Similar Biologics" approved in Australia

\begin{tabular}{|c|c|c|}
\hline $\begin{array}{c}\text { Common } \\
\text { name/Generic of } \\
\text { Similar Biologics } \\
\text { Approved } \\
\end{array}$ & Name of the Company with Brand Name & Indications for use \\
\hline Epoetin alfa & Hexal- Epoetin alfa Hexal(126) & $\begin{array}{l}\text { To treat anaemia, cancer and chronic } \\
\text { kidney failure conditions }\end{array}$ \\
\hline Epoetin lambda & $\begin{array}{l}\text { Sandoz- Aczicrit (127-128) } \\
\text { Sandoz- Grandicrit(127-128) } \\
\text { Novartis Pharmaceuticals Australia- } \\
\text { Novicrit(127-128) }\end{array}$ & $\begin{array}{l}\text { To treat anaemia, cancer and chronic } \\
\text { kidney failure conditions }\end{array}$ \\
\hline Insulin glargine & Eli Lilly Australia- Basaglar(128-129) & To treat diabetes. Long acting insulin \\
\hline Follitropin alfa & Finox Biotech- Bemfola $(128,130)$ & To treat infertility \\
\hline Infliximab & Hospira (Pharmbio)- Inflectra(128,131) & $\begin{array}{l}\text { To treat ankylosing spondylitis, } \\
\text { Crohn's disease, psoriatic arthritis, } \\
\text { psoriasis, rheumatoid arthritis, } \\
\text { ulcerative colitis }\end{array}$ \\
\hline Filgrastim & $\begin{array}{l}\text { Hospira- Nivestim(128,132) } \\
\text { Teva Pharma Australia Pty Ltd- } \\
\text { Tevagrastim(128,133) } \\
\text { Sandoz- Zarzio(134) }\end{array}$ & $\begin{array}{l}\text { To treat cancer, haematopoietic stem } \\
\text { cell transplantation, neutropenia }\end{array}$ \\
\hline Somatropin & $\begin{array}{l}\text { Sandoz- Omnitrope }(128,135) \\
\text { SciGen Australia- SciTropin A }(128,136)\end{array}$ & $\begin{array}{l}\text { To treat growth disturbance due to } \\
\text { chronic renal insufficiency, pituitary } \\
\text { dwarfism, Turner syndrome }\end{array}$ \\
\hline Rituximab & Roche- Rituximab(137) & $\begin{array}{l}\text { To treat Non-Hodgkin lymphoma, } \\
\text { leukaemia, rheumatoid arthritis }\end{array}$ \\
\hline Trastuzumab & Roche- Herceptin(138) & To treat breast and gastric cancer \\
\hline Bevacizumab & Roche- Avastin(139) & $\begin{array}{l}\text { To treat brain tumours, breast, lung } \\
\text { cancer }\end{array}$ \\
\hline
\end{tabular}


Ranibizumab

Adalimumab

Etanercept
AbbVie Pty Ltd- Humira(141)

Novartis Pharmaceuticals AustraliaLucentis(140)

Pfizer Australia Pty Ltd- Enbrel(142)
To treat visual impairment due to choroidal neovascularisation, secondary to pathologic myopia

To treat rheumatoid arthritis, psoriatic arthritis, ankylosing spondylitis, Crohn's disease

To treat rheumatoid arthritis, ankylosing spondylitis, psoriatic arthritis and plaque psoriasis

\section{INDIA}

In India, certain companies have been selling $\mathrm{r}$ DNA based therapeutic products such as recombinant human insulin and hepatitis $B$ vaccine from imported sources since 1989 after obtaining marketing approvals under the then Drugs Laws. In 1992 in an article entitled Biotechnology Industries in India (143), the potentials for the setting up of a wide range of biotechnology products in the country drew the attention of several entrepreneurs. Potentials for the production of recombinant hepatitis-B vaccine were also elaborated in the article. The first r-DNA based product of Hepatitis B vaccine (antigen) was experimented upon at Institute of Microbial Technology (IMTECH), Chandigarh using recombinant Hansenula polymorpha (Pichia angusta) based yeast production system coding for hepatitis B surface antigen ( $\mathrm{HBsAg}$ ); the organism was grown in fermentation vessels and the protein was isolated, purified and characterized in 1995 through a collaboration among Transgene Biotek, Hyderabad, Rhein Biotech, Germany and IMTECH. Later, Transgene set up its own production facilities at Hyderabad and conducted trials utilizing its own recombinant formulation after obtaining the necessary regulatory approvals .After completing the Phase-III trials, Transgene sold the entire technology package to Serum Institute of India Pvt. Ltd, Pune and the latter introduced the product as Gene $V a c-B$, an r-DNA Hepatitis-B vaccine (144) in 2000. Simultaneously in 1993, another project was pursued by Shantha Biotechnique, Hyderabad for developing a r-DNA based Hepatitis-B vaccine. Shantha requested Osmania University to permit its molecular biology expert from the Department of Microbiology to carry out initial work on the project and Shantha also paid for the cost of consumables besides upgrading the laboratory. Initial experiments to develop a suitable clone were carried out in the laboratory to develop recombinant Pichia pastoris expression host coding for hepatitis B surface antigen (HBsAg). After the expression system was developed, Shantha moved to the Centre for Cellular and Molecular Biology (CCMB), Hyderabad hiring CCMB space and CCMB equipment to perfect the technology further, using Shantha's own scientists who were in the mean time recruited. At this juncture, Shantha obtained substantial financial support from Oman in 1995 and started constructing its own R\&D and production facility at Medhchal. Shantha pursued the developmental efforts vigorously. All rounded support was also accorded by the government. The combined efforts resulted in the development and introduction of the first r-DNA based hepatitis -B vaccine produced in Pichia pastoris (as the commercial recombinant expression host for the first time in the world). The pharmaceutical formulation of HBsAg was first evaluated in animals and had thereafter undergone the full-scale evaluation through Phase-I, Phase-II and Phase-III clinical trials. The active ingredient and the components in the formulation were rigorously tested and characterized physico-chemically, biologically and immunologically (in animals) before undertaking the human trials. The finished formulation was found to be comparable to Smith Kline Beecham's Engerix-B (Hepatitis B recombinant vaccine). Engerix-B was the inventor's product, which was therefore considered as the reference product.The commercial product, Shanvac-B of Shantha Biotech was introduced in India on August 18, 1997 for sale after obtaining all the regulatory approvals under Indian Environment (Protection) Act (EPA) and Indian Drugs Act. The expression host was obtained by Shantha from Phillips Petroleum Company in Bartlesville and Research Corporation Technologies (RCT), USA in 1993. Pichia system produces recombinant proteins and grows efficiently in media containing methanol. Phillips and RCT made available the $P$. pastoris 
expression system to Shantha for research use initially and subsequently for commercial use; the royalty on the commercial use of Pichia pastoris was waived by the owners. Shantha's experiments enabled the classification of Pichia pastoris as GRAS (Generally Regarded As Safe) for other products. The consequence of this decision by Phillips and RCT had been an enormous gain for India for exploration and development of local knowledge of r-DNA technology in numerous product development strategies. In India, the use of genetically modified substances is being regulated under the Environment (Protection) Act 1986 and Rules 1989 as well as the Indian Drugs Act. Guidelines have been issued from time to time to ease the application process. A large number of rDNA-based biologics have been authorized for use in the country utilizing these acts and rules. Up to the end of 2008, twenty two numbers recombinant therapeutic drugs were approved for marketing in India utilizing the above rules and guidelines (145).

The Indian government through its Environment (Protection) Act 1986 and the Rules1989 piloted several Indian developmental efforts through the statutory Institutional Biosafety Committee, Review Committee on Genetic Manipulations and the Genetic Engineering Approval Committee to steer the local efforts to develop manufacturing technologies for r-DNA products such as cytokines( interferons and interleukins) , G-CSF \& GM-CSF, Erythropoietins, Insulin, Streptokinase, t-PA etc besides Hepatitis-B vaccine and these acts were linked and coupled with the Indian Drugs Act to provide regulatory approvals ,authorizing the use of such products as medicines for the people. Indian development of r-DNA products was the result of combined efforts of the Department of Biotechnology (Ministry of Science \& Technology), Ministry of Environment \& Forests and the Director General of Health Services of the Ministry of Health during the period up to 2012. The Department of Biotechnology up to this period had played a key role in setting standards and in allowing hitherto unapproved recombinant DNA products for experimentation in India under the Environment Protection Act through research mode which enabled this sunrise industry to overcome all the initial teething problems in research and developmental experimentation, which situation was not dealt with by any other Indian law. Thereafter, the "Guidelines on Similar Biologics" were prepared jointly by the Indian Central Drugs Standard Control Organization (CDSCO) and the Department of Biotechnology (DBT) for " similar biologic" in 2012(146), which was revised and updated in 2016(147).India is therefore on a mature footing in dealing with "similar biologics". The Indian industry has gained considerable maturity; there is a pool of trained man-power in place and the statutory authorities have obtained extensive hands-on experience in dealing with modern biological products including "similar biologics".

The different kinds of "similar biologics" that have been approved in India are provided as per details given in Table 7 .

Table 7: "Similar Biologics" approved in India

\begin{tabular}{|c|c|c|}
\hline $\begin{array}{c}\text { Common name/Generic of } \\
\text { Similar Biologics } \\
\text { Approved }\end{array}$ & Name of the Company with Brand Name & Indications for use \\
\hline r-Hepatitis B vaccine & $\begin{array}{l}\text { Shantha Biotech- Shanvac-B(148-150) } \\
\text { Serum Institute- Gene Vac-B(148-151) } \\
\text { Biological Evans- Hep B(148,149,150,152) } \\
\text { Wockhardt- Biovac-B }(148,149,150,153) \text { Bharat Biotech- } \\
\text { Revac-B(148,149,150,154) }\end{array}$ & $\begin{array}{l}\text { To protect against } \\
\text { hepatitis } \mathrm{B} \text { infection }\end{array}$ \\
\hline G-CSF/Filgrastim & $\begin{array}{l}\text { Emcure- Emgrast(155) } \\
\text { Claris Life Sci- Fegrast(156) } \\
\text { RPG-LS- Frastim(157) } \\
\text { Dr. Reddy’s Lab- Grafeel(158) } \\
\text { Intas- Neukine(159) } \\
\text { Biocon- Nufil(160) } \\
\text { Reliance Life Sci- Religrast(161) }\end{array}$ & $\begin{array}{l}\text { Stimulates proliferation } \\
\text { and differentiation of } \\
\text { granulocytes }\end{array}$ \\
\hline $\begin{array}{l}\text { r-Peg G-CSF/Pegylated G- } \\
\text { CSF }\end{array}$ & $\begin{array}{l}\text { Intas- Neupeg }(162) \\
\text { Gennova- Pegex(163) } \\
\text { Dr. Reddy’s Lab- Peg-grafeel(164) }\end{array}$ & $\begin{array}{l}\text { Long acting G-CSF to } \\
\text { treat cancer, stimulates } \\
\text { proliferation and } \\
\text { differentiation of } \\
\text { granulocytes }\end{array}$ \\
\hline
\end{tabular}


r-Erythropoietin/ rErythropoietin alfa/rDarbepoetin alfa

r-EGF

r-Streptokinase

Human Insulin

Insulin glargine/Insulin Analogues

Recombinant hGMCSF/Molgramostim

Interferon alfa-2a

Pegylated r-interferon alfa 2a

Interferon alfa-2b
Intas- Eporec(165)

Serum Institute- Repoitin(166)

Shantha Biotech- Shanpoietin(167)

Zydus Cadila- Zyrop(168)

Ranbaxy- Ceriton(169)

Cadila Pharma- Cadicrit(170)

Emcure- Epofer(171)

Intas- Epofit/Erykine(172)

Biocon- Erypro(173)

Reliance Formulation- Relipoietin(174)

Wockhardt- Wepox(175)

Cipla- Actorise(176)

Dr. Reddy's Labs- Cresp(177)

Torrent Pharma- Darbatitor(178)

Bharat Biotech- Regen-D 150(179)

Biocon- Myokinase(180)

Shantha Biotech- Shankinase(181)

Biocon- Insugen(182)

Wockhardt- Wosulin(183)

Novo Nordisk India- Human Actrapid(184)

Eli Lilly- Humulin(185)

Gland Pharma- Huminsulin(186)

Biocon- Basalog(182,187)

Wockhardt- Glaritus(188)

Novo Nordisk- Novorapid Penfill (100 iu) (Insulin

Lispro)(189)

Eli Lilly- Humalog(190)

Torrent Pharma- Human Actrapid(191)

Ranbaxy- Macrogen(192)

Emcure- Oncocare(193)

Taj Pharma- Interferon alfa-2a(194)

Roche- Pegasys(195-196)

Intas- Intalfa(197)

Reliance Life Sciences- Reliferon(198)

Shantha Biotech- Shanferon(199)

Zydus Cadila- Zavinex(200)
To treat anemia, chronic kidney failure and various cancer

To treat diabetic foot ulcer

Anti-thrombolytic agent, to treat blood clot

For treating diabetes mellitus

For treating diabetes mellitus, long acting insulin and others
Immunomodulator; functions as a cytokine and is a white blood cell growth factor

To treat chronic hepatitis $\mathrm{C}$, chronic hepatitis $B$, certain $T$ cell lymphomas, particularly mycosis fungoides

To treat chronic hepatitis $\mathrm{C}$ and chronic hepatitis B. Long acting interferon alfa $2 \mathrm{a}$

Used for the treatment of chronic hepatitis $\mathrm{C}$, chronic hepatitis $\mathrm{B}$, hairy cell leukemia, chronic myelogenous leukemia, multiple myeloma, follicular 


\begin{tabular}{|c|c|c|}
\hline & & $\begin{array}{l}\text { lymphoma, carcinoid } \\
\text { tumor, and malignant } \\
\text { melanoma }\end{array}$ \\
\hline Pegylated r-interferon alfa & Ranbaxy- Pegliton(201) & $\begin{array}{l}\text { For treatment of } \\
\text { hepatitis } \mathrm{C}\end{array}$ \\
\hline Interferon beta-1a & Reliance Life Sciences- Relibeta(202) & $\begin{array}{l}\text { To treat multiple } \\
\text { sclerosis }\end{array}$ \\
\hline $\begin{array}{l}\text { Interferon } \\
\text { gamma/Interferon gamma } \\
\text { 1b }\end{array}$ & Geltec Pvt. Ltd- Actimmune(203) & $\begin{array}{l}\text { To reduce the repeated } \\
\text { occurrences } \\
\text { severity of serious } \\
\text { infections associated } \\
\text { with chronic } \\
\text { granulomatous disease }\end{array}$ \\
\hline r-Human Somatropin & $\begin{array}{l}\text { Eli Lily India- Humatrope(204) } \\
\text { LG Life Sciences- Eutropin(205) } \\
\text { P. Upjohn- Genotropin(206) } \\
\text { Novo Nordisk- Norditropin Nordilet(207) } \\
\text { Merck Specialities Pvt Ltd -Saizen(208) }\end{array}$ & $\begin{array}{l}\text { To treat children's } \\
\text { growth disorders and } \\
\text { adult growth hormone } \\
\text { deficiency disorder }\end{array}$ \\
\hline Nimotuzumab & Biocon- BIOMAb EGFR(209) & $\begin{array}{l}\text { To treat head and neck } \\
\text { cancer; binds to the } \\
\text { epidermal growth factor } \\
\text { receptor (EGFR) that } \\
\text { controls cell division }\end{array}$ \\
\hline Rituximab & $\begin{array}{l}\text { Hetero- Maball(210) } \\
\text { Intas- MabTas(211) } \\
\text { Dr. Reddy’s Labs- Reditux(212) } \\
\text { Emcure- Ikgdar(213) }\end{array}$ & $\begin{array}{l}\text { To treat chronic } \\
\text { lymphocytic leukemia } \\
\text { and non-Hodgkin's } \\
\text { lymphoma }\end{array}$ \\
\hline r-Blood Factor VIII & Baxter India- Recombinate(214) & $\begin{array}{l}\text { Indicated to treat } \\
\text { hemophilia A for the } \\
\text { prevention and control } \\
\text { of hemorrhagic } \\
\text { episodes and for the } \\
\text { perioperative } \\
\text { management of patients } \\
\text { with hemophilia A }\end{array}$ \\
\hline r-Blood Factor VII & Novo Nordisk India- NovoSeven(215-216) & $\begin{array}{l}\text { Indicated to treat } \\
\text { hemophilia } \mathrm{A} \text { for the } \\
\text { prevention and control } \\
\text { of hemorrhagic } \\
\text { episodes and for the } \\
\text { perioperative } \\
\text { management of patients } \\
\text { with hemophilia A }\end{array}$ \\
\hline \multirow{3}{*}{$\begin{array}{l}\text { Follitropin alfa (follicle } \\
\text { stimulating hormone) }\end{array}$} & \multirow[b]{2}{*}{ Intas Pharma- Folisurge(217) } & Treatment of infertility \\
\hline & & Treatment of infertility \\
\hline & Reliance Life Sciences- FostiRel(218) & \\
\hline
\end{tabular}




\section{Follitropin beta (follicle stimulating hormone)}

Teriparatide-parathyroid hormone

\section{Abciximab}

Adalimumab

\section{Trastuzumab}

\section{Human Chorionic} gonadotrophin hormone/rhCG

\section{Recombinant human Luteinizing Hormone}

\section{Recombinant human} serum albumin

\section{Cetuximab}

Etanercept

Infliximab

\section{Rasburicase/Urate Oxidase}

Intas Pharma-Terifrac(219)

Intas Pharma- Teriparatide(219)

Reliance Life Sciences- AbcixiRel(220)

Torrent Pharma- Adfrar(221)

Zydus Cadila- Exemptia(222)

Biocon- CanMab(223)

Reliance Life Sciences- Choriorel(224)

Merck Biopharma India- Luveris(225)

Bharat Biotech- Human recombinant serum albumin(226)

Merck- Erbitux(227)

Cipla- Etacept(228)

Intas Pharma- IntaCept(229)

Ranbaxy- Infimab(230)

Virchow Biotech- Rasburicase(231)

Ranibizumab

Intas Pharma- Razumab(232)
To treat osteoporosis

To treat heart conditions

To treat rheumatoid arthritis, psoriatic arthritis, ankylosing spondylitis, Crohn's disease, ulcerative colitis

To treat HER2-positive metastatic breast cancer

Used in women undergoing assisted reproductive techniques (ART) such as in-vitro fertilization (IVF) to bring about ovulation trigger

To treat female infertility.

Used to replace lost fluid and help restore blood volume in trauma, burns and surgery patients.

To treat advanced squamous cell carcinoma of head and neck. Also used for colorectal cancer treatment

To treat autoimmune diseases

To treat autoimmune diseases

Effective for prevention and management of hyperuricemia in patients who are at high risk of developing TLS.

To treat degenerative conditions of the eye 


\section{SOUTH KOREA}

The Ministry of Food and Drug Safety (MFDS) of the Government of South Korea through its National Institute of Food and Drug Safety evaluation conducts the scientific evaluation of medicines developed by pharmaceutical companies for use in South Korea. The guidelines on evaluation of biosimilar products were introduced by the country in July 2009; these guidelines were based on the WHO, EU and Japanese guidelines. These guidelines have been revised from time to time incorporating the latest revisions in the notification of 2015(233). The guidelines describe principles of comparability exercise between a reference product and biosimilar product in terms of quality, non-clinical properties and clinical studies. The safety, efficacy and quality of the "similar biologics" are compared with an already marketed reference product. During the developmental stage, the "similar biologics" should be in the same dosage form, posology and root of administration as of the reference product. Other "similar biologics" cannot be used a reference product. The regulatory framework in South Korea is essentially based on a 3-tier system governed firstly by the Pharmaceutical Affairs Act and secondly by notifications of the regulations on review and authorization of biological products and thirdly on the guidelines issued by the country for the evaluation of "similar biologics". Product-based Korean biosimilar guidelines have been published for several products namely erythropoietin, somatropin, granulocyte colony-stimulating factor and monoclonal antibodies (234).

Table 8: "Similar Biologics" approved in South Korea

\begin{tabular}{|c|c|c|}
\hline $\begin{array}{l}\text { Common name/Generic } \\
\text { of Similar Biologics } \\
\text { Approved }\end{array}$ & Name of the Company with Brand Name & Indications for use \\
\hline Etanercept & $\begin{array}{l}\text { Merck/Samsung Bioepis- Brenzys(235-236) } \\
\text { Hanwha Chemical- Davictrel(236-237) }\end{array}$ & $\begin{array}{l}\text { To treat axial } \\
\text { spondyloarthritis, psoriatic } \\
\text { arthritis, plaque psoriasis } \\
\text { and heumatoid arthritis }\end{array}$ \\
\hline Trastuzumab & Celltrion- Herzuma(236,238) & $\begin{array}{l}\text { To treat HER2-positive } \\
\text { metastatic breast cancer }\end{array}$ \\
\hline r-Human Somatropin & Sandoz- Omnitrope $(236,239)$ & $\begin{array}{l}\text { To treat children's growth } \\
\text { disorders and adult growth } \\
\text { hormone deficiency }\end{array}$ \\
\hline Infliximab & $\begin{array}{l}\text { Celltrion- Remsima }(236,240) \\
\text { Merck/Samsung Bioepis- Renflexis }(236,241)\end{array}$ & $\begin{array}{l}\text { Various arthritis, psoriasis, } \\
\text { ulcerative colitis and } \\
\text { Crohn's disease }\end{array}$ \\
\hline
\end{tabular}

The different kinds of "similar biologics" that have been approved in South Korea are provided as per details given in Table 8.

\section{CHINA}

The Centre for Drug Evaluation at the China Food and Drug Administration issued guidelines on "similar biologics" on $28^{\text {th }}$ February 2015. According to the Chinese guidelines, a similar biologic product is a "therapeutic biological product" similar to an authorized reference product in terms of quality, safety and efficacy. With reference to clinical studies, the Chinese guidelines suggest that clinical trials for "similar biologics" should start with PK and PD studies based on which clinical efficacy and safety studies should be conducted. The comparability between the similar biologic product and the reference product can be made for quality assessment and non-clinical studies based on clinical PK, PD and PK/PD studies. The Chinese guidelines suggest that the clinical immunogenicity assessment should be based on outcome of non-clinical immunogenicity assessment. When such studies would suggest similarity of the similar biologic product with the reference product then only limited clinical assessment is required. The approval of "similar biologics" has not been assigned to a separate abbreviated approval pathway. The approval pathways are subjected to the same pathways as are applicable to innovative biologics. Further, for the reference product the Chinese authorities require that the product should be approved in China. Reference products approved by foreign regulatory authorities and not approved in China are not acceptable as the reference product. 
On Interchangeability, no guidelines have yet been elaborated in the Chinese guidelines (242-243). The guidelines do not however specifically incorporate any ICH recommendations in relation to quality, efficacy and safety requirement. Therefore, in essence, though the guidelines are similar to the ones based on WHO and EMA guidelines, in details there are considerable differences. The Chinese guidelines represent a significant progress within the territory for promoting the development of "similar biologics". In the meantime, according to certain reports, a whopping 282 genetically engineered drugs and vaccines have already been approved for commercialization in China of which 21 products are innovative and the rest are copy biologics, according to the data of Southern Medicines Economic Research Institute of the China State Food and Drug Administration as quoted elsewhere(244). All these "similar biologics" are stated to have been approved after Phase III clinical trials.

The first r-DNA product manufactured and marketed in China(245) was recombinant human interferon alpha $1 \mathrm{~b}$ in 1993 by M/s Shenzhen Kexing Biotech Co. Ltd., Shenzhen. Shenzhen also manufactures erythropoietin and G-CSF(246). Recombinant human interferon alpha $1 \mathrm{~b}$ is also manufactured by Beijing Tri-Prime Gene Pharmaceutical Co. Ltd. and is marketed as Hapgen injection(247). There are several other full-fledged modern biotech companies in China which include Shenzhen Kangta (248) importing and supplying r-HBV vaccine, Shenyang SanShen manufacturing Interferon, Interleukin 2 and Erythropoietin, Beijing ShuangLu Pharmaceutical Co. Ltd. manufacturing G-CSF, Interleukin 11 and Anhui Anke manufacturing human growth hormone(245). Hangzhou Jiuyuan Gene Engineering Co. Ltd., Zhejiang is one of the earliest company of China dealing with r-DNA products and it introduced the first biosimilar product in China after Phase III study, the product JILIFENP which is the first rh G-CSF approved in China(249). The company also produces JIJUFEN, which is a recombinant Human Interleukin-11 presented as Injection. Shenzhen Watsin Genetech Ltd., Shenzhen produces recombinant epidermal growth factor and markets the product as GeneTime and GeneSoft (250-251).

In another report on China of 2008 providing information on top 60 Chinese biotech companies, it has been mentioned that majority of the Chinese biotech companies are dedicated to the development and commercialization of follow-on biologics primarily because Chinese investment on
R\&D is not adequate. Most Chinese biotech firms are small in size (except the China National Biotech Group), most companies do not have adequate fund to take up intensive $R \& D$ and to carry out up gradation of facilities to global standards and as a consequence these companies could not obtain western cGMP certification or WHO pre-qualification. Under the present circumstances, outsourcings of technologies are anticipated to be major drivers for the development of China's biotech industry during the next one decade(252).

Presently in China, more than $90 \%$ of China's population including the urban employees, urban residents and the rural cooperatives are covered with basic medical insurance. However, as the life expectancy is increasing and as the number of aged population is on the rise and further, as the personal income of a section of population is rising considerably, these conditions would catalyze the expansion of private insurance business for reimbursing the expensive treatment costs of cancer or chronic diseases as these costs are mostly not reimbursed for patients in the existing hospitals (253). Chinese individuals have to meet such costs from out of pocket expenses. These conditions would catalyze the local production of several "similar biologics" in the country.

\section{ASEAN COUNTRIES}

The Association of Southeast Asian Nation (ASEAN) represent 10 Member States of ASEAN region comprising Indonesia, Malaysia, Thailand, Philippines, Singapore, Darussalam, Vietnam ,Lao PDR, Myanmar and Cambodia. The total population in the region during 2012 was estimated(254) at 608.4 million. The ASEAN is committed to creating closer and deeper coordination among the 10 members in economy, society \& culture, politics and security through developing single market and production base, raising competitiveness, supporting equitable development and integrating the ASEAN in to the global economy where healthcare improvement of the region is an integral part of the development strategies(255-256).The ASEAN Harmonization Scheme for pharmaceutical harmonization initiative has been taken up to establish cooperation among the ASEAN countries to minimize efforts and to speed their access to new medicines for the people. Efforts initiated in 1992 by creating a Consultative Committee for Standards and Quality and thereafter the Pharmaceutical Product Working Group was established in 1999 where procedures for incorporation of international standards such as 
ICH and WHO guidelines were incorporated for adoption in the ASEAN Common Technical Dossier (ACTD) for registration of pharmaceuticals for human use (257). However, this document is not meant for use for registration of "similar biologics". Indeed, the ACTD is not yet fully implemented in all ASEAN Member states for biologics and biosimilars (258). Certain countries have however taken steps to register marketing and usage of "similar biologics" in their territory. In Malaysia, for example, the draft guidelines were prepared in March 2008 and were adopted in August 2008(259). Malaysian guidelines have abbreviated pathway in place for registration of "similar biologics". Singapore (260) and Philippines (261) also have their guidelines for "similar biologics". Thailand adopts in-country registration regime for biosimilar products and these registration requirements are aligned with the guidelines of US FDA and European Medical Agency. Thailand has also published specific guidelines for preparing registration application dossier for certain biosimilar products such as erythropoietin, interferon beta, follicle stimulating hormones and monoclonal antibodies. However, incidence of adverse events of pure red cell aplasia in the country has been very high (262) from the use of approved follow-on erythropoietin products indicating therefore that the country has to go a long way in standardization and vigilance procedures. The other ASEAN countries such as Darussalam, Lao PDR, Myanmar and Cambodia are yet to come out with their guidelines for approval of "similar biologics" in their territory. The details of the "similar biologics" approved in ASEAN countries are provided in Table 9. Data could be obtained for Malaysia and Philippines only.

\section{CIS COUNTRIES}

The Commonwealth of Independent States (CIS) is a region which was formed during the breakup of the Soviet Union. Presently, the CIS member countries are Russia, Uzbekistan, Kazakhstan, Belarus, Azerbaijan, Tajikistan, Kyrgyzstan, Moldova and Armenia with a total population of 234.5 million (2015), of which Russia represents around $62.3 \%$ followed by Uzbekistan which represents around $13 \%$ and Kazakhstan which represents around 7\%; the 3 countries together represent about $83 \%$ of the CIS countries' population. In terms of per capita GDP, Russia tops the list (US\$ 14240 per capita in 2012) followed by Kazakhstan (US\$ 11700 per capita in 2012), further followed by Azerbaijan (US\$ 7500 per capita in 2012) and Belarus (US\$ 6710 per capita in 2012) (271). The market potential of "similar biologics" appears to be more in countries such as Russia, Kazakhstan, Azerbaijan and Belarus. Manufacturers and/or suppliers of "similar biologics" in CIS countries would have to chalk out a slew of initiatives to facilitate faster approval of such products within the territories of each individual country. The pharmaceutical sector in CIS nations is growing at over $10 \%$ per year annually in terms of value. However, in these countries most of the expenses on costly medicines are paid individually by patients. Further, most CIS countries do not have the right kinds of infrastructure and expertise to manufacture and test "similar biologics" within their territory. These countries are therefore expected to be dependent upon the availability of such products from cheaper sources without compromising on quality, safety and efficacy. However, even within the existing constraints, several CIS countries have taken steps to introduce "similar biologics" within their territory on a faster mode. The following are the country-wise initiatives taken by the CIS countries in this direction.

\section{RUSSIA}

The Russian Federation announced its Federal Law on $12^{\text {th }}$ April 2010(272) elaborating how biologics including "similar biologics" could be adopted in the country for marketing and use. The law also provided provisions for accelerated marketing approval procedure to biosimilars (273). By October 2015, 14 formulations of G-CSF (filgrastim) were approved for marketing of which 7 were produced locally and another 15 formulations of erythropoietins alpha, beta and theta were also registered in Russia. Of these 15 erythropoietins formulations, 8 were manufactured locally. Neupomax produced by Pharmstandard and Leucostin Neupomax produced by BIOCAD received marketing approval based on limited clinical information. In the country, the state cancer hospitals are able to buy their requirements through electronic auctions. The hospitals submit a bid in common name of the drug and an anonymous contractor can offer the drug quoting lowest price (274). In such a situation of the market condition, introduction of biosimilar product from outside sources seems to be much easier in Russia. Under such policy conditions, local development may get delayed.

\section{OTHER CIS COUNTRIES}

There is yet no announced procedure for biosimilar (abbreviated) pathway in place or data/marketing exclusivity for reference biologic products in 
Uzbekistan, Kazakhstan, Belarus, Azerbaijan, Tajikistan, Kyrgyzstan and Armenia(275). No information was available on the internet for Moldova. The Republic of Kazakhstan (276) had in the meantime announced its procedures for the marketing approval of "similar biologics" within its territory. Other countries are also poised to develop their guidelines for such products; in the meantime, the existing rules and procedures under the Drugs Act of the CIS countries would be the guiding acts for providing marketing approval of similar biologics within their territories. Without well-laid down procedures however, there would be considerable heterogeneity in the procedures of decision making from one country to the other. In the meantime, these countries would feel the urge for obtaining "similar biologics" by a section of population requiring these medicines to treat several chronic diseases including cancer. Such patients would have to procure these medicines from the local distributors at more expensive prices as there are anticipated to be less marketing competition in these regions.

\section{AFRICAN COUNTRIES INCLUDING SUB- SAHARAN REGION}

Africa represents as one of the world's poorest region and therefore a large chunk of diseases are shared by the region. According to the World Health Organization (WHO), the sub-Saharan Africa carries about a quarter of the global dieses burden (277). Presently, national efforts in most African countries to treat childhood diseases by vaccination and communicable anti-microbial diseases by antibiotic and anti-bacterial substances have proven beneficial and such efforts have reduced the mortality to a considerable extent. But yet, the high cost of treatment of life threatening viral diseases (such as HIV, HBV, HCV and others) and chronic health conditions emanating from diabetes, arthritis, cardio-vascular disease conditions and a wide range of cancer requiring long-term treatment by use of biologic drugs which are extremely expensive are putting greater strain on the already resource-poor healthcare system of all African countries. Efforts to make available the cheaper versions of biologic drugs namely the "similar biologics" are therefore a matter of great desire and expectation by the people of the region. The population of Africa region spread in 58 African countries was 1153.3 million as of July 01, 2015, of which population in countries representing individually up to $1 \%$ or more, was contributed by 26 nations while larger ones contributing individually to more than $3 \%$ of the total were 11; the most populated one was Nigeria, representing nearly $16 \%$ of the total African population.

The average annual population growth rate of the entire region was high at $2.68 \%$ and in some regions the figures reported were $5.49 \%$ at Eritrea and $5.95 \%$ in South Sudan (278). Therefore on one hand, while the region is burdened with high population growth rate, poverty enshrouds heavy disease load; on the top of it the induction of

Table 9: "Similar Biologics" approved in ASEAN countries

\begin{tabular}{lll}
\hline $\begin{array}{l}\text { Common name/Generic } \\
\text { of Similar Biologics } \\
\text { Approved }\end{array}$ & Name of the Company with Brand Name & Indications for use \\
\hline MALAYSIA & Sandoz- Scitropin(263-264) & \\
\hline Somatropin & Sandoz- Binocrit(263,265) & $\begin{array}{l}\text { Growth disturbance in children and } \\
\text { growth hormone deficiency in adults }\end{array}$ \\
Epoetin alfa & $\begin{array}{l}\text { Renal anaemia, cancer and predonation } \\
\text { preparation for autologours and } \\
\text { allogeneic blood transfusion }\end{array}$ \\
Filgrastim & $\begin{array}{l}\text { Sandoz- Zarzio }(263,266) \\
\text { Hospira- Nivestim(263,267) }\end{array}$ & Cancer, HSCT and chronic neutropenia
\end{tabular}

r-Human insulin Biocon- Insugen(263,268)

Diabetes mellitus

PHILLIPPINES

Epoetin alfa Kalbe Farma- Hemapo(269)

Renal anaemia, cancer and predonation preparation for autologours and allogeneic blood transfusion 
modern life style in a section of well-to-do population inducing sedentary habits is causing the overload of spread of chronic diseases and cancer. In African region therefore the demand of modern biologics including "similar biologics" is increasing.

In 2014, the regulatory experts and the representatives of the pharmaceutical industry from 11 African countries had a discussion to find means for introducing "similar biologics" in African countries (279). Yet at the present moment only 3 African countries namely South Africa, Egypt and Nigeria have been able to set out guidelines for the introduction of "similar biologics" in their region.

In the Republic of South Africa, the Medicines Control Council (MCC) of the Department of Health had published (280)the guidelines for the approval of biosimilar medicines in the country in August 2014. The guidelines are applicable to biological medicines containing wellcharacterized recombinant DNA-derived therapeutic proteins that can be shown to be similar to a biological medicine (reference biological product) registered in South Africa. Vaccines are excluded from the product range. Biosimilar medicines are considered to be similar, but not necessarily identical, in terms of quality, safety and efficacy to an already registered reference biological medicine. The MCC guidelines are essentially similar to the guidelines of US FDA, EU EMA and WHO guidelines. Several biologic formulations are available for sale in South Africa and these are imported and sold after obtaining marketing authorization. The cost of these medicines, especially in Oncology, is very high. Annual treatment cost of cancer has been stated to be more than US\$ 120,000 for a course of monoclonal antibodies(281)and is therefore considered unaffordable even by the upper middle class in the region.

The Egypt Ministry of Health, Central Administration for Pharmaceutical Affairs, General Registration Department from its Department of Biological Products Registration had published its guidelines for registration of biosimilar products (282) which are effective from September 2014. Egypt had earlier announced the approval process of biologic drugs (283) within their territory since 2009. Eight different categories of biological drugs including similar biologics are authorized for marketing in Egypt as per details in Table 10.

Table 10: "Similar Biologics" approved in Egypt (284)

\begin{tabular}{|c|c|c|}
\hline $\begin{array}{c}\text { Common name/Generic } \\
\text { of Similar Biologics } \\
\text { Approved }\end{array}$ & Name of the Company with Brand Name & Indications for use \\
\hline Epoetin alfa/Epoetin & $\begin{array}{l}\text { Vacsera- Epojet (285) } \\
\text { EIPICO-Egypt- Epoform (286) } \\
\text { SEDICO - Epoetin Sedico (287) }\end{array}$ & $\begin{array}{l}\text { To treat Anaemia, Cancer and } \\
\text { Chronic kidney failure condition }\end{array}$ \\
\hline G-CSF/Filgrastim & SEDICO - Filgrastim (288) & $\begin{array}{l}\text { Stimulates proliferation and } \\
\text { differentiation of granulocytes }\end{array}$ \\
\hline Human Insulin & $\begin{array}{l}\text { SEDICO - Insulin H BIO NPH (289) } \\
\text { SEDICO- Insulin H BIO R (290) } \\
\text { SEDICO- Insulin H MIX (291) }\end{array}$ & For treating diabetes mellitus \\
\hline hCG & $\begin{array}{l}\text { Amriya- Chorionic(292) } \\
\text { EIPICO-Egypt- EPIFASI (292) } \\
\text { El Nile- Chorionic Gonadotrophin(292) }\end{array}$ & $\begin{array}{l}\text { Used in women undergoing assisted } \\
\text { reproductive techniques (ART) such } \\
\text { as in-vitro fertilization (IVF) to } \\
\text { bring about ovulation trigger }\end{array}$ \\
\hline $\begin{array}{l}\text { Recombinant } \\
\text { Interferon Alfa-2a }\end{array}$ & Rhein Mina Pharm- Reiferon (293) & $\begin{array}{l}\text { To treat chronic hepatitis C, chronic } \\
\text { hepatitis B, certain } r \text {-cell } \\
\text { lymphomas, particularly mycosis } \\
\text { fungoides }\end{array}$ \\
\hline $\begin{array}{l}\text { PEG Interferon Alpha } \\
\text { 2a }\end{array}$ & Mini Pharm- Reiferon Retard (294) & Long acting interferon alfa $2 \mathrm{a}$ \\
\hline FSH & $\begin{array}{l}\text { EIPICO-Egypt- EPIGONAL (295) } \\
\text { SEDICO- FSH (296) }\end{array}$ & To treat female infertility \\
\hline
\end{tabular}




\begin{tabular}{lll}
\hline r-HGH & SEDICO - Somatropin (297) & To treat dwarfism \\
Urokinase & SEDICO - Angikinase (298) & $\begin{array}{l}\text { Anti-thrombolytic agent, to treat } \\
\text { blood clot }\end{array}$ \\
Streptokinase & SEDICO - Sedonase (299) & $\begin{array}{l}\text { Anti-thrombolytic agent, to treat } \\
\text { blood clot }\end{array}$ \\
\hline
\end{tabular}

In Nigeria, the Nigerian National Agency for Food and Drug Administration and Control (NAFDAC) had published the final guidance document for the registration of biosimilar drugs (300) in December 2012. The guidelines are based on the comparability exercise for biosimilar products and are designed to show that the products have highly similar quality attributes when compared to the Reference Biotechnology Product (RBP). RBP is a product used as the comparator for head-to-head comparability studies with a biosimilar product in order to show similarity in terms of quality, safety and efficacy. A bio-therapeutic product that was licensed on the basis of a full registration dossier in Nigeria and / or by a Stringent Regulatory Authority (SRA) can serve as a RBP. Nigeria has defined SRA as the National Drug Regulatory Authorities of countries who are members, observers or associates of the International
Conference on Harmonization (ICH) of Technical Requirements for Registration of Pharmaceuticals for Human Use. A large number of similar biologics have been registered(301) in Nigeria which includes three brands of filgrastim, nine brands of erythropoietin, seventy six brands of insulin including glargine, one brand of streptokinase, one brand of interferon alfa, one brand of luteinizing hormone, one brand of rituximab, two brands of trastuzumab and one brand of ranibizumab. It is however not clear about how many of these biologics are products of original inventors and how many are registered as "similar biologics' or biosimilars. Companies from outside the country have got their biological products registered in Nigeria; the products are being imported and sold in Nigeria as shown in Table11.

Table 11. "Similar Biologics" approved in Nigeria (301)

\begin{tabular}{|c|c|c|}
\hline $\begin{array}{c}\text { Common } \\
\text { name/Generic of } \\
\text { Similar Biologics } \\
\text { Approved } \\
\end{array}$ & Name of the Company with Brand Name & Indications for use \\
\hline Filgrastim & $\begin{array}{l}\text { Centre For Genetic Engineering And } \\
\text { Biotechnology (CGEB), Cuba- Hebervital } \\
\text { Laboratorio Pablo Cassara, Argentina- } \\
\text { Neutrofil } \\
\text { F. Hoffmann-La Roche Ltd, Basel- Neupogen }\end{array}$ & $\begin{array}{l}\text { Stimulates proliferation } \\
\text { differentiation of granulocytes }\end{array}$ \\
\hline Erythropoietin & $\begin{array}{l}\text { Wockhardt Ltd., India- Wepox 4000/Wwpox } \\
4000 \text { IV } \\
\text { Shandong Kexing Bioproducts Co. Ltd., } \\
\text { Shandong, China- Eposino } \\
\text { Roche Dignostics, Mannheim- Recormon } \\
\text { Laboratorio Pablo Cassara SRL, Argentina- } \\
\text { Epogen }\end{array}$ & $\begin{array}{l}\text { To treat Anaemia, Cancer and Chronic } \\
\text { kidney failure conditions }\end{array}$ \\
\hline Streptokinase & CGEB, Cuba - Heberkinase & $\begin{array}{l}\text { Anti-thrombolytic agent, to treat blood } \\
\text { clot }\end{array}$ \\
\hline Interferon alfa & CGEB, Cuba - Hebeon Alfa R & $\begin{array}{l}\text { To treat chronic hepatitis } \mathrm{C} \text {, chronic } \\
\text { hepatitis } \mathrm{B} \text {, certain } \mathrm{T} \text {-cell lymphomas } \\
\text { particularly mycosis fungoides }\end{array}$ \\
\hline $\begin{array}{l}\text { Luteinizing Hormone } \\
\text { (LH) }\end{array}$ & Laboratories Serono, Switzerland - Pergonal 75 & To treat female infertility \\
\hline
\end{tabular}


Insulin

Rituximab

Trastuzumab

Ranibizumab
Eli Lily- Humulin 30/70 and other brands Novo Nordisk- Lente Insulin, Actrapid and other brands

Vacsera Egyptian Organization for Biological Product and Vaccines, Egypt- Human Insulin R-Vacsera Biotin

Marvel Life Sciences Ltd, UK- Bosulin L Wockhardt Ltd., India- Wosulin and other brands

Biocon- Insugen $\mathrm{N}$ and other brands Sanofi Aventis- Insuman Basal and other brands

F.Hoffmann-La Roche Ltd., Basel- Mabthera

Genentech Inc., California- Herceptin

Novartis Pharma, Switzerland- Lucentis
For treating diabetes mellitus

To treat Non-Hodgkin lymphoma, leukaemia, rheumatoid arthritis

To treat breast and gastric cancer

To treat visual impairment due to choroidal neovascularisation, secondary to pathologic myopia
In other regions of Africa, efforts are being made to catch up and come up with policies for the fast introduction of "similar biologics" in their territories. In the meantime, the load of chronic diseases including cancer continues to rise in this region. At the same time it is to be emphasized that authentic data on the prevalence and mortality due to cancer in the entire African region is particularly sparse. Only a few cancer registries exist in the entire African region and approximately only $8 \%$ of the population was covered earlier in such surveys (302). The published figures are inadequate to accurately assess the population suffering from cancer; it is anticipated that suffers for cancer would be much more. Globally, cancer was identified to be the cause of $15 \%$ of all deaths calculated to be about eight million people in 2010 , which figure was considered to be greater than the combined deaths caused by HIV, tuberculosis and malaria (303). There is therefore a great need to pay attention to treating cancer in this region by all countries together and in this context the abundant availability of quality "similar biologics" at affordable costs can play a significant role in human welfare. International bodies like the United Nations (UN), the World Bank (WB) and Multilateral Agencies like the World Health Organization (WHO), Pan American Health Organization (PAHO), The United Nation Children's Fund (UNICEF) and The United Nation Development Programme (UNDP) can be activated jointly by the world community for the global control of chronic diseases especially cancer in poorer African countries by making available effective medicines for treatment. In this context, taking up a project by international bodies to make "similar biologics" available at affordable prices to all poor countries would go a long way in human welfare endeavour.

\section{OTHER COUNTRIES}

Presently worldwide there are 197 independent countries of which 193 are the members of the United Nations (304). The population density, disease pattern, per capita GDP, industrialization status, and development of pharmaceutical industries especially the infrastructures for the manufacture of biologicals vary considerably among these countries. In many countries, because of lower population, setting up of facilities for modern biologicals for local consumption is not economically justifiable/feasible. In numerous others, the local capabilities are yet inadequate. There are certain other countries such as Turkey(305)and some others that have made considerable progress in framing their guidelines for the introduction of "similar biologics" in their territories. There are also other countries where guidelines are yet to be formulated (306). Information from all such regions is not included in this review.

\section{CONCLUDING REMARKS}

"Similar biologics" industry is still a nascent one in many countries. The industry is fuelled by expectations of saving/prolonging the lives of patients suffering from certain chronic life- 
threatening diseases and concomitantly arousing astounding hopes to the society of huge expected savings from their use across the countries. The profitability of "similar biologics" industry is also anticipated to be high. Therefore, the governments, the industry investing in "similar biologics", the payers including the patients are all interested in the development of this industry faster in their territories.

At present, there are globally more than 150 reference biologic products and that about 40 numbers of these have sales of more than USD 1 billion per year. The "similar biologics" are emulating from these reference-biologic products as the "inventor's biologic products" are going offpatent.

If any one or more of the existing or new "similar biologics" companies can capture even 5$10 \%$ of the market, these would mean considerable business and profits besides establishment of the image of global presence. This is therefore the right time and a precious opportunity for the entrepreneurs for venturing in to right projects on "similar biologics" in both developing and developed world.

In all countries, the regulations for approval of "similar biologics" are based on proving the comparability of the products to an already approved reference product. The comparability measurements are defined in terms of quality, nonclinical physico-chemical identification of the "similar biologics" as also evaluation of manufacturing processes and finally a clinical evaluation. In all the countries, the abbreviated pathway package requires full quality assessment of the active ingredient by physico-chemical methods using most sophisticated instruments. There is a relaxation however in the generation of data for the finished formulation through comparative clinical studies which situation varies from country to country. All efforts are directed to assess the characteristics of the "similar biologics" with the reference biologics to ensure that the "similar biologics" are as good as the reference biologics.

The liberalization in the extent of data generation for "similar biologics" compared to the corresponding reference biologic drug should not be seen as an issue for conjecturing that "similar biologics" may be inferior to their corresponding reference biologic drug counterpart. All "similar biologics" are required to be physico-chemically, biologically and immunologically similar to the reference products at the time of marketing authorization and approval. The relaxation in the generation of extensive clinical data through comparative clinical studies is on the assumption that extensive data had already been generated earlier for the reference biologics and that exhaustive duplication would lead to increase in costs of development, which can be avoided. This would also ease faster introduction of "similar biologics" to serve the patients.

Even though the evaluation criteria for the approval of "similar biologics" are based on proving the comparability of the products to an already approved reference product, regulators of several developed countries presently believe that data generation and documentation are not exhaustively standardized and therefore data generated in one country cannot always be accepted in another country. As a result, manufacturers are required to generate some part of comparability information once again when they wish to register their "similar biologics" in such newer regions.

Every "similar biologic" product is also named by the manufacturer by an international nonproprietary name (INN) on the label besides its brand name. Even though "similar biologic" products are approved by the regulators only after being convinced that these are comparable physico-chemically, biologically and immunologically to the reference product and that these are as safe and as efficacious as the reference biologic, several countries strongly feel that for post-market surveillance for pharmacovigilance purposes each "similar biologic" should be distinctly identifiable even from their INN. In other words, the INN for "similar biologics" needs modification. Scientifically, while every new pharmaceutical formulation introduced in to the market requires pharmacovigilance in order to ensure long-term safety, addressing the problem for "similar biologics" through INN modification does not seem to be the most desirable way firstly because alteration of INN distorts an established scientific understanding and secondly because this process may foster an impression that "similar biologics" may be an inferior product. The very purpose of introducing simplified procedures for fast introduction of "similar biologics" at more affordable prices to serve the ailing patients gets diluted. The surmountable efforts of entrepreneurs to develop more competitive "similar biologic" technologies all over the world also gets a jolt.

One alternative way to identify is to prefix or suffix a code for each new-entrant "similar biologics" on the brand name instead on the INN; for companies introducing "similar biologics" only 
in INN, the prefix or suffix be added on the INN for them.

The "inventor's biologic products" have contributed significantly during the last three decades in treating chronic diseases including cancer. "Similar biologics" are subsets of inventor's biologics. It is anticipated therefore that introduction of "similar biologics" of quality proven to be comparable to the "inventor's biologics" and available at cheaper prices would enable more usage of such products for treating more patients and the situation shall contribute considerably more to human welfare at more affordable costs.

Although "similar biologics" are essentially very similar to the inventor's biologics, the technologies for their manufacture are not simple. The business is highly science and technology based. High technical skill, strong discipline and maintenance of uniform conditions throughout the processing cycles are the cornerstones for success in order to minimize batch to batch variations in the product qualities. Countries developing "similar biologics" industries get technologically elevated in multiple facets.

At the present moment, all countries throughout the world do not have a uniform policy standard for approval process for "similar biologics". While the developed countries are making fast progress, the space for the highly populated developing countries entering in to this business is to first feed its own country and then to venture to enter in to the regions of developed country markets, where feasible. It is anticipated that baring a few, most developing countries would find it difficult to get their "similar biologics" registered in developed country markets for the time being; the developing countries would have to gather more experience, especially in technological aspects. Sadly, in several developing countries, the existing infrastructure is inadequate for the establishment of "similar biologics" industries.

For becoming a prominent player in "similar biologics" from the developing countries all round development and up gradation is required. In this context while the local regulatory authorities need to be upgraded with matching infrastructure, concomitantly institutional skill development as well as the R\&D infrastructure of the country in modern biology need to be upgraded. Medical infrastructure should be strong. Efficient bio-based industries should be in place. In addition, every opportunity should exist for collaborations with technologically rich countries and companies. These are some of the important factors on which developing countries can ponder to establish their "similar biologics" industry in their territories on a strong footing.

\section{ACKNOWLEDGEMENTS}

The assistance of Dhruva Chatterjee, Personal Assistant and Computer Executive- SOMPRADIP PUBLISHERS AND CONSULTANTS, New Delhi, in systematically typing the manuscript and arranging the References properly is gratefully acknowledged. The author also acknowledges Ms. Deepali Ghosh, the other partner of the company, for encouraging and providing all the financial support to complete the manuscript. The author has no conflict of interest regarding the content of this article.

\section{REFERENCES}

1 Member states of the World Trade Organization. In Wikipedia, The Free Encyclopaedia,https://en.wikipedia.org/w/index.ph p?title=Member states of the World Trade Org anization\&oldid $=733397525$ accessed on August 07, 2016

2 Greg EW, Chang YJ, Saydah S, Cowie CC, Garfield S, Geiss L and Barker L, Trends in Death Rates Among U.S. Adults With and Without Diabetes Between 1997 and 2006, Diabetes Care, Vol.35, June 2012, pp 1252-1257, http://care.diabetesjournals.org/content/diacare/35/ 6/1252.full.pdf

3 Kremer JM, COMET's path, and the new biologicals in rheumatoid arthritis, Volume 372, No. 9636, pp 347-348, 2nd August 2008, http://www.thelancet.com/journals/lancet/article/P IIS0140-6736(08)61001-6/fulltext

4 Roger VL, Go AS, Lloyd-Jones DM,Benjamin EJ,Berry JD,Borden WB et al

Heart Disease and Stroke Statistics-2012 Update, Circulation, American Heart Association, Inc., 2012; $125, \quad$ pp e2-e220, http://circ.ahajournals.org/content/125/1/e2.full.pd f?download=true

5 NIH Surveillance, Epidemiology, and End Results Program, http://seer.cancer.gov/explorer/application.php?sit $\mathrm{e}=1 \&$ data type $=2 \&$ stat type $=2 \&$ compare $B y=$ race $\&$ chk sex $1=1 \&$ chk sex $3=3 \&$ chk sex $2=2 \&$ ch k race $1=1 \&$ chk age range $1=1 \&$ advopt precisi on=1\&showDataFor $=$ sex 1 and age range $1 \&$ se riesOrder=1-1 accessed on August 07, 2016

6 New Medicines Yield Significant Progress against Serious Diseases, Phrma, September 2012, pp 1-9, http://www.phrma.org/sites/default/files/pdf/medic al advances final 9.4.12.pdf

7 Ghielmini M, Schmitz SF, Cogliatti SB, Pichert G, Hummerjohann J, Waltzer U, Fey MF, Betticher DC, Martinelli G, Peccatori F, Hess U, Zucca E, 
Stupp R, Kovacsovics T, Helg C, Lohri A, Bargetzi $\mathrm{M}$, Vorobiof $\mathrm{D}$ and Cerny $\mathrm{T}$, Prolonged treatment with rituximab in patients with follicular lymphoma significantly increases event-free survival and response duration compared with the standard weekly x 4 schedule., Blood. 2004 Jun 15; 103(12):4416-23. Epub 2004 Feb 19. https://www.ncbi.nlm.nih.gov/pubmed/14976046

8 Vogelaar L, Spijker AV, C Janneke and Woude CJ van der, The impact of biologics on health-related quality of life in patients with inflammatory bowel disease, Clinical and Experimental Gastroenterology 2009:2 101-109, https://www.ncbi.nlm.nih.gov/pubmed/21694833

9 Boyle RM, The Use of Biologics in Cancer Therapy, US Pharm. 2010, 35(3), (Oncology suppl): pp 4-7, https://www.uspharmacist.com/article/the-use-ofbiologics-in-cancer-therapy

10 Saad ED, Overall Survival: Patient Outcome, Therapeutic Objective, Clinical Trial End Point, or Public Health Measure, Journal OF Clinical Oncology, Vol. 30, No. 15, 2012, pp 1750-1754, http://jco.ascopubs.org/content/30/15/1750.full.pdf + html

11 The Voice of the Patient: A Series of Reports from FDA's Patient-Focused Drug Development Initiative,2013, http:/www.fda.gov/ForIndustry/UserFees/Prescrip tionDrugUserFee/ucm $368342 . \mathrm{htm}$ accessed on August 09, 2016

12 Vogeli C, Shields AE, Lee TA, Gibson TB, Marder WD, Weiss KB, and Blumenthal D, Multiple chronic conditions: prevalence, health consequences, and implications for quality, care management, and costs, J Gen Intern Med. 2007 Dec;22 Suppl 3: pp 391-395, https://www.ncbi.nlm.nih.gov/pmc/articles/PMC2 150598/pdf/11606 2007 Article 322.pdf

13 Biosimilar, In Wikipedia, The Free Encyclopedia, https://en.wikipedia.org/w/index.php?title=Biosim $\underline{\text { ilar\&oldid }=737177869}$ accessed on September 02, 2016

14 Guidelines on Similar Biologics: Regulatory Requirements for Marketing Authorization in India,

http://cdsco.nic.in/writereaddata/Proposed\%20Gui delines\%20for\%20Similar\%20Biologic\%202016. pdfaccessed on December 27, 2016

15 Azevedo VA, Sandorff E, MA, Siemak B and Halbert RJ, Potential Regulatory and Commercial Environment for Biosimilars in Latin America, Value in Health Regional Issues, Volume 1, Issue 2, December 2012, pp 228-234, http://www.sciencedirect.com/science/article/pii/S 2212109912000684

16 Rader RA, Biosimilars in the Rest of the World: Developments in Lesser-Regulated Countries, Winter 2013/2014, BioProcessing Journal, pp 4147 http://www.bioinfo.com/Biosimilars ROW.pdf

17 Young D, Sandoz Enbrel Copycat Next Biosimilar to get panel treatment, Scrip-Pharma Intelligence,
https://scrip.pharmamedtechbi.com/SC065385/San doz-Enbrel-Copycat-Next-Biosimilar-To-GetPanel-Treatmentaccessed on September 05, 2016

18 Loftus P, FDA approves rheumatoid knockoff, The Wall Street Journal, http://www.wsj.com/articles/fda-approvesrheumatoid-arthritis-biosimilar1459890781accessed on September 05, 2016

19 WHO-International Non-proprietary Names (INN) Working Document 05.179 Update 2011for biological and biotechnological substances: http://www.who.int/medicines/services/inn/BioRe v2011.pdfaccessed on September 05, 2016

20 U.S. Department of Health and Human Services, Food and Drug Administration, August 2015,Nonproprietary Naming of Biological Products, Guidance for Industry, http://www.fda.gov/downloads/drugs/guidanceco mplianceregulatoryinformation/guidances/ucm459 987.pdfaccessed on September 13, 2016

21 USAN Council- https://www.ama-assn.org/aboutus/usan-councilaccessed on September 13, 2016

22 Brennan Z, June 2016,FDA Calls on Companies to Select 10 Suffixes for Biosimilar, Biologic Names, http://raps.org/Regulatory-

Focus/News/2016/06/01/25038/FDA-Calls-onCompanies-to-Select-10-Suffixes-for-BiosimilarBiologic-Names-by-Preference/accessed on September 13, 2016

23 US FDA, National Drug Code Directory, https://www.accessdata.fda.gov/scripts/cder/ndc/a ccessed on September 13, 2016

24 Olson K, ALLIANCE FOR SAFE BIOLOGIC MEDICINE - PRESCRIBER SURVEY, https://safebiologics.org/wpcontent/uploads/2012/09/ASBM-Survey1.pdfaccessed on September 13, 2016

25 Me Cina J, Fanikos J, Mitton P, McCrea M and Churchill W, Medication Errors in a PharmacyBased Bar-Code-Repackaging Center, American Journal of Health-System Pharmacy 63(2): pp 165168 , February 2006, http://www.medscape.com/viewarticle/521316

26 Casadevall N, Felix T, Strober B E and Warnock D G, Similar Names for Similar Biologics, BioDrugs 28(5) · July 2014, DOI: 10.1007/s40259014-0099-9,pp 439-444, https://www.researchgate.net/publication/2637404 15 Similar_Names for_Similar_Biologics

27 IBEF, http://www.ibef.org/download/Biosimilarsin-India-30312.pdfaccessed on September 13, 2016

28 Lond D, The Business of Biosimilar, IMS Health, March 2015 , https://www.healthcaredistribution.org/ /media/pd fs/education/2015-dmc-presentations/tue-f3biosimilars-biz.ashx?la=enaccessed on September 13, 2016

29 Ecker DM, Jones SD and Howard L Levine HL (2015) The therapeutic monoclonal antibody market, mAbs, 7:1, 9-14, DOI: 10.4161/19420862.2015.989042, 
http://www.tandfonline.com/doi/pdf/10.4161/1942 $\underline{0862.2015 .989042 \text { ?needAccess }=\text { true }}$

30 Biosimilar medicines, EMA, http://www.ema.europa.eu/ema/index.jsp?curl=pa ges/special topics/document listing/document lis ting 000318.jspaccessed on September 13, 2016

31 Biologics Price Competition and Innovation, FDA, http://www.fda.gov/downloads/Drugs/GuidanceC omplianceRegulatoryInformation/ucm216146.pdfa ccessed on September 13, 2016

32 Fenwick \& West, A Comparison of US and EU Biosimilars Regimes, https://www.fenwick.com/FenwickDocuments/01$\underline{06-}$

12 Comparison US EU Biosimilars Regimes.pd faccessed on September 13, 2016

33 Chaudhuri S, Multinationals and Monopolies, Pharmaceutical Industry in India after TRIPS, WPS No. 685/ November 2011, pp 1-38, https://www.iimcal.ac.in/sites/all/files/pdfs/wps 6 85 0.pdf

34 Castanheira LG, Barbano DB and Rech N,Current development in regulation of similar biotherapeutic products in Brazil, Biologicals. 2011 Sep;39(5):308-11. doi: 10.1016/j.biologicals.2011.06.021. Epub 2011 Aug 24

http://www.ncbi.nlm.nih.gov/pubmed/21868247

35 Shaping the biosimilars opportunity: A global perspective on the evolving biosimilars landscape, IMS HEALTH, 2011, http://weinberggroup.com/pdfs/Shaping the biosi miliars_opportunity_A_global_perspective on th e evolving biosimiliars landscape.pdfaccessed on September 14, 2016

36 EMA, Authorised Biosimilars, http://www.ema.europa.eu/ema/index.jsp?curl=pa ges/special topics/document_listing/document_lis ting 000318.jsp, September 14, 2016

37 Grabowski H, Guha R and Salgado M ,Biosimilar competition: lessons from Europe, Nature Reviews Drug Discovery 13, pp 99-100 (2014), http://www.nature.com/nrd/journal/v13/n2/full/nrd 4210.html

38 Emerton DA, Profitability in the Biosimilars Market, 11(6)s, pp 6-14, BioProcess Int., 2013, http:/www.bioprocessintl.com/wpcontent/uploads/2014/06/Profitability-in-theBiosimilars-Market.pdf

39 Biosimilar, In Wikipedia, The Free Encyclopedia https://en.wikipedia.org/w/index.php?title=Biosim ilar\&oldid $=750189044$ accessed on September 14, 2016

40 Mulcahy AW, Predmore Z, and Mattke S, RAND Corporation, The Cost Savings Potential of Biosimilar Drugs in the United States, Perspective, pp 1-16, https://www.rand.org/content/dam/rand/pubs/pers pectives/PE100/PE127/RAND PE127.pdf

41 Aitken M, IMS Institute for Health Informatics, Delivering on the Potential of Biosimilar Medicines, The Role of Functioning Competitive
Markets, March 2016, pp 1-36, https://www.imshealth.com/files/web/IMSH\%20I nstitute/Healthcare\%20Briefs/Documents/IMS In stitute Biosimilar_Brief_March 2016.pdf

42 State of the Biopharmaceutical Industry 2016, BioPharma-Reporter.com, http://www.biopharmareporter.com/Library/Survey-Report-State-of-theBiopharmaceutical-Industry-2016, accessed on September 14, 2016

43 Spadiut O,Capone S, Krainer F,Glieder A and Herwig C, Microbials for the production of monoclonal antibodies and antibody fragments, Trends in Biotechnology,January 2014 32(1) pp $54-60$, https://www.ncbi.nlm.nih.gov/pmc/articles/PMC3 906537/

44 Li F, Vijayashankaran N, Shen A(Y), Kiss R and Amanullah A,Cell culture processes for monoclonal antibody production, mAbs, 2010 SepOct; 2(5): pp 466-479, http://www.ncbi.nlm.nih.gov/pmc/articles/PMC29 $\underline{58569 /}$

45 Rader RAand Langet ES, Biopharmaceutical Manufacturing: Historical and Future Trends in Titers, Yields, and Efficiency in Commercial-Scale Bioprocessing, BioProcessing Journal, Winter 2014/2015, Volume 13/Issue 4, pp 47-54, http://www.biopharma.com/J134-RaderLanger.pdf

46 Shevitz J, Bonham-Carter J, Lim J and Sinclair A , An Economic Comparison of Three Cell Culture Techniques, BioPharm International, Volume 24, Issue

http://www.biopharminternational.com/economiccomparison-three-cell-culture-techniques

47 Warikoo V, Godawat $\mathrm{R}$, Brower $\mathrm{K}$, Jain $\mathrm{S}$, Cummings D, Simons E, Johnson T, Walther J, Yu M, Wright B, McLarty J, Karey KP, Hwang C, Zhou W, Riske F and Konstantinov K, Integrated Continuous Production of Recombinant Therapeutic Proteins, Biotechnology and Bioengineering, Vol. 109, No. 12, December, 2012, $\mathrm{pp}$ 3018-3029, https://www.ncbi.nlm.nih.gov/pubmed/22729761

48 Carter JB and Shevitz J A Brief History of Perfusion Biomanufacturing, BioProcess International, 9(9), October 2011, pp 24-28, http://www.bioprocessintl.com/upstreamprocessing/bioreactors/a-brief-history-ofperfusion-biomanufacturing-322322/

49 Kelley $\mathrm{B}$, Industrialization of $\mathrm{mA} b$ production technology: the bioprocessing industry at a crossroads, MAbs, 2009 Sep-Oct;1(5), pp 443-452, https://www.ncbi.nlm.nih.gov/pmc/articles/pmid/2 $\underline{0065641 /}$

50 Carstens JN, Clarke H R G, and Jansen J P, Perfusion! Jeopardy or the ultimate advantage, CMC Biologics, September 2009, pp 341, http://www.bioprocessintl.com/wpcontent/uploads/2014/06/BPI_CMC Biologics W ebcast.pdf 
51 Whitford WG, Supporting Continuous Processing with Advanced Single-Use Technologies, BioProcess International, 11(4)s April 2013, pp 4652, $\quad$ http://www.bioprocessintl.com/wpcontent/uploads/2014/06/Supporting-ContinuousProcessing-with-Advanced-Single-Use$\underline{\text { Technologies.pdf }}$

52 DECHEMA Biotechnologie, 2nd Edition, March 2012,

http://dechema.de/dechema_media/StatPap_Single Use 2011 englisch-p-4298-view image-1called by-dechema-original_site-dechema eVoriginal page-124930.pdfaccessed on September 15,2016

53 Trotter AM, Adoption of Single-use Disposable Technology in Biopharma IndustriesManufacturing, Economic and Regulatory Issues to Consider, American Pharmaceutical Review, http://www.americanpharmaceuticalreview.com/F eatured-Articles/39300-Adoption-of-Single-useDisposable-Technology-in-Biopharma-IndustriesManufacturing-Economic-and-Regulatory-Issuesto-Consider/accessed on September 15, 2016

54 Commonwealth of Independent States, In Wikipedia, The Free Encyclopaedia. https://en.wikipedia.org/w/index.php?title=Comm onwealth_of Independent States\&oldid $=7416935$ 88accessed on September 15, 2016

55 WHO Guidelines on evaluation of similar bio therapeutic products(SBPs), http://who.int/biologicals/publications/trs/areas/bio logical therapeutics/TRS 977 Annex 2.pdfacces sed on September 15, 2016

56 Biosimilars: Questions and Answers Regarding Implementation of the Biologics Price Competition and Innovation Act of 2009- Guidance for Industry, http://www.fda.gov/downloads/drugs/guidanceco mplianceregulatoryinformation/guidances/ucm 444 661.pdfaccessed on November 16, 2016

57 Biosimilar, In Wikipedia, The Free Encyclopedia, https://en.wikipedia.org/w/index.php?title=Biosim ilar\&oldid $=725424886$ accessed on November 16 , 2016

58 Sandoz Press Release, http://www.sandoz.com/media center/press releas es news/global_news/2015 $03 \quad 06$ fda approves first biosimilar_zarxio from sandoz.shtmlaccesse $\mathrm{d}$ on November 16, 2016

59 US FDA Press Announcement, http://www.fda.gov/newsevents/newsroom/pressa nnouncements/ucm436648.htmaccessed on November 16, 2016

60 US FDA News and Events, http://www.fda.gov/NewsEvents/Newsroom/Press Announcements/ucm494227.htmaccessed on November 16, 2016

61 Regulatory Affairs Professionals Society, http://www.raps.org/Regulatory-

Focus/News/2016/08/30/25739/FDA-ApprovesThird-Biosimilar-in-US-First-for-AmgensBlockbuster-
Enbrel/\#sthash.iAu6rpHE.dpufaccessed

on

November 16, 2016

62 FDA approves Amjevita, a biosimilar to Humira, http://www.fda.gov/NewsEvents/Newsroom/Press

Announcements/ucm522243.htmaccessed on November 16, 2016

63 Health Canada, Guidance For Sponsors: Information and Submission Requirements for Subsequent Entry Biologics (SEBs), http://www.hc-sc.gc.ca/dhp-mps/brgtherap/applicdemande/guides/seb-pbu/seb-pbu 2010eng.phpaccessed on September 16, 2016

64 GAB

Online, http://www.gabionline.net/Biosimilars/General/Su bsequent-entry-biologics-approved-inCanadaaccessed on November 21, 2016

65 Health Canada, http://www.hc-sc.gc.ca/dhpmps/prodpharma/sbd-smd/drugmed/sbd smd 2009 omnitrope 113380eng.phpaccessed on September 19, 2016

66 Health Canada, http://www.hc-sc.gc.ca/dhpmps/prodpharma/sbd-smd/drugmed/sbd smd 2014 inflectra 159493eng.phpaccessed on September 19, 2016

67 Health Canada, http://www.hc-sc.gc.ca/dhpmps/prodpharma/sbd-smd/drug-

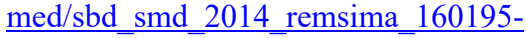
eng.phpaccessed on September 19, 2016

68 Health Canada, http://www.hc-sc.gc.ca/dhpmps/prodpharma/rds-sdr/drug-med/rds-sdrgrastofil-156897-eng.phpaccessed on September 19, 2016

69 Health Canada, http://www.hc-sc.gc.ca/dhpmps/prodpharma/sbd-smd/drug-med/sbd-smd2016-brenzys-184793-eng.phpaccessed on September 19, 2016

70 EMA Guideline, 2006, http://www.ema.europa.eu/docs/en_GB/document library/Scientific guideline/2009/09/WC500003 920.pdfaccessed on November 11, 2016

71 EMA, 2015 , http://www.ema.europa.eu/docs/en_GB/document library/Scientific guideline/2015/01/WC500180 219.pdfaccessed on November 11, 2016

72 GABI Online, http://www.gabionline.net/Biosimilars/General/Bi osimilars-approved-in-Europeaccessed

on November 21, 2016

73 EMA, http://www.ema.europa.eu/ema/index.jsp?curl=pa ges/medicines/human/medicines/002835/human med 001790.jsp\&mid=WC0b01ac058001d124acc essed on November 11, 2016

74 EMA, http://www.ema.europa.eu/ema/index.jsp?curl=pa ges/medicines/human/medicines/000727/human med 000621.jsp\&mid=WC0b01ac058001d124acc essed on November 11, 2016

75 EMA,

http://www.ema.europa.eu/ema/index.jsp?curl=pa ges/medicines/human/medicines/000725/human 
med_000675.jsp\&mid=WC0b01ac058001d124acc essed on November 11, 2016

76 EMA,

http://www.ema.europa.eu/ema/index.jsp?curl=pa ges/medicines/human/medicines/000726/human med 000768.jsp\&mid=WC0b01ac058001d124acc essed on November 11, 2016

77 EMA, http://www.ema.europa.eu/ema/index.jsp?curl=pa ges/medicines/human/medicines/000872/human med 001031.jsp\&mid=WC0b01ac058001d124acc essed on November 11, 2016

78 EMA, http://www.ema.europa.eu/ema/index.jsp?curl=pa ges/medicines/human/medicines/000760/human med 001051.jsp\&mid $=$ WC0b01ac058001d124acc essed on November 11, 2016

79 EMA, http://www.ema.europa.eu/ema/index.jsp?curl=pa ges/medicines/human/medicines/003956/human $\underline{\text { med 001798.jsp\&mid }=W C 0 b 01 \mathrm{ac} 058001 \mathrm{~d} 124 \mathrm{acc}}$ essed on November 11, 2016

80 EMA, http:/www.ema.europa.eu/ema/index.jsp?curl=pa ges/medicines/human/medicines/000826/human med 000676.jsp\&mid=WC0b01ac058001d124acc essed on November 11, 2016

81 EMA, http://www.ema.europa.eu/ema/index.jsp?curl=pa ges/medicines/human/medicines/000918/human med 000791.jsp\&mid $=$ WC0b01ac058001d124acc essed on November 11, 2016

82 EMA, http://www.ema.europa.eu/ema/index.jsp?curl=pa ges/medicines/human/medicines/002150/human med 001688.jsp\&mid=WC0b01ac058001d124acc essed on November 11, 2016

83 EMA, http://www.ema.europa.eu/ema/index.jsp?curl=pa ges/medicines/human/medicines/001142/human med 001344.jsp\&mid=WC0b01ac058001d124acc essed on November 11, 2016

84 EMA,http://www.ema.europa.eu/ema/index.jsp?cu $\mathrm{rl}=$ pages $/$ medicines $/$ human $/$ medicines $/ 000825 / \mathrm{hu}$ man_med_001015.jsp\&mid=WC0b01ac058001d1 24accessed on November 11, 2016

85 EMA,

http://www.ema.europa.eu/ema/index.jsp?curl=pa ges/medicines/human/medicines/000827/human med 001089.jsp\&mid=WC0b01ac058001d124acc essed on November 11, 2016

86 EMA, http://www.ema.europa.eu/ema/index.jsp?curl=pa ges/medicines/human/medicines/000917/human med 001170.jsp\&mid=WC0b01ac058001d124acc essed on November 11, 2016

87 EMA, http://www.ema.europa.eu/ema/index.jsp?curl=pa ges/medicines/human/medicines/004020/human med 001980.jsp\&mid=WC0b01ac058001d124acc essed on November 11, 2016
88 EMA,

http://www.ema.europa.eu/ema/index.jsp?curl=pa ges/medicines/human/medicines/002778/human med 001677.jsp\&mid=WC0b01ac058001d124acc essed on November 11, 2016

89 EMA,

http://www.ema.europa.eu/ema/index.jsp?curl=pa ges/medicines/human/medicines/002576/human med 001682.jsp\&mid $=$ WC0b01ac058001d124acc essed on November 11, 2016

90 EMA, http://www.ema.europa.eu/ema/index.jsp?curl=pa ges/medicines/human/medicines/004007/human med 001944.jsp\&mid=WC0b01ac058001d124acc essed on November 11, 2016

91 EMA,http://www.ema.europa.eu/ema/index.jsp?cu $\mathrm{rl}=$ pages/medicines/human/medicines/002615/hu man med 001734.jsp\&mid=WC0b01ac058001d1 24accessed on November 11, 2016

92 EMA,

http://www.ema.europa.eu/ema/index.jsp?curl=pa ges/medicines/human/medicines/002608/human med 001689.jsp\&mid=WC0b01ac058001d124acc essed on November 11, 2016

93 EMA,

http://www.ema.europa.eu/ema/index.jsp?curl=pa ges/medicines/human/medicines/000607/human med_000946.jsp\&mid $=$ WC0b01ac058001d124acc essed on November 11, 2016

94 EMA, http://www.ema.europa.eu/ema/index.jsp?curl=pa ges/medicines/human/medicines/000602/human med 001125.jsp\&mid=WC0b01ac058001d124acc essed on November 11, 2016

95 EMA,

http://www.ema.europa.eu/ema/index.jsp?curl=pa ges/medicines/human/medicines/004368/smops/P ositive/human_smop_001057.jsp\&mid=WC0b01a c058001d127accessed on November 11, 2016

96 EMA,

http://www.ema.europa.eu/ema/index.jsp?curl=pa ges/medicines/human/medicines/003916/smops/P ositive/human smop 001062.jsp\&mid=WC0b01a c058001d127accessed on November 11, 2016

97 Guideline for the quality, safety and efficacy of follow-on biological medicinal Products, Japan Generic Medicines Association, http://www.jga.gr.jp/english/wpcontent/uploads/sites/4/2011/03/Interim_Translati on of Notification 0304007Followon_Biologics1.pdfaccessed on September 20, 2016

98 Pharmaceutical Administration and Regulations in Japan, NIHS, Japan, http://www.nihs.go.jp/mhlw/yakuji/yakujie 20110502-02.pdfaccessed on September 20, 2016

99 GABI Online, http://www.gabionline.net/Biosimilars/General/Bi osimilars-approved-in-Japanaccessed on November 21, 2016

100 Worldometers, http://www.worldometers.info/geography/how- 
many-countries-in-latin-america/accessed

on September 20, 2016

101 Latin America pharmaceutical sales, Americas Market Intelligence, https://static1.squarespace.com/static/557dd429e4 b035c8591b78e0/t/55f9aa33e4b0f520d4e4d4fe/14 42425395064/Article 2 - AMI -

LatAm to_lead_global_pharma_sales_growth 20141107.pdfaccessed on September 20, 2016

102 Ministry of Health Brazil, National Health Surveillance Agency, http://bvsms.saude.gov.br/bvs/saudelegis/anvisa/2 010/res0055 $16 \quad 12 \quad 2010$. htmlaccessed on September 21,2016

103 CAPÍTULO I, DAS DISPOSIÇÕES INICIAIS, Seção I (English: CHAPTER I OF THE INITIAL PROVISIONS, Section I), http://bvsms.saude.gov.br/bvs/saudelegis/anvisa/2 010/anexo/anexo res0055 16 12 2010.pdfaccess ed on September 21, 2016

104 Cox O, Biotechnological Product Roadblocks in Mexico, Regulatory Focus, www.raps.org/WorkArea/DownloadAsset.aspx?id $=5131$ accessed on September 21, 2016

105 TWN Info Service on Intellectual Property Issues, Third World Network, http://www.twn.my/title2/intellectual_property/inf o.service/2015/ip150201.htmaccessed on September 21, 2016

106 ANMAT, Argentina, http://www.anmat.gov.ar/webanmat/Legislacion/ Medicamentos/Decreto150-1992.pdfaccessed on September 21, 2016

107 Decree 7075 Argentina, http://www.anmat.gov.ar/webanmat/retiros/octubr e/Disposicion 7075-2011.pdfaccessed

on September 21, 2016

108 Decree 7729 , Argentina, http://www.anmat.gov.ar/webanmat/retiros/novie mbre/Disposicion 7729-2011.pdfaccessed on September 21, 2016

109 Ministerio De Salud, Peru, ftp://ftp2.minsa.gob.pe/normaslegales/2012/RM89 92012 MINSA.pdfaccessed on September 22, 2016

110 Instituto Nacional de Higiene Rafael Rangel, Venezuela, http://www.inhrr.gob.ve/pdf/rc pdf/proyecto de n orma_PBS.pdfaccessed on September 22, 2016

111 Proposed biosimilars guidelines for Chile, GABI, http://www.gabionline.net/Guidelines/Proposedbiosimilars-guidelines-for-Chileaccessed on September 22, 2016

112 Ministerio de Salud Pública y Asistencia Social, http://cretec.org.gt/wpcontent/files_mf/normatecnica67v22015.pdfaccess ed on September 22, 2016

113 Ecuador Regulations, http://www.controlsanitario.gob.ec/wpcontent/uploads/downloads/2014/08/A-3344Reglamento-para-la-obtenci\%C3\%B3n-deregistro-sanitario-de-medicamentos-
biol\%C3\%B3gicos.pdfaccessed on September 22, 2016

114 Regulatory framework in Cuba, WHO, http://www.who.int/medicines/areas/quality safet $\mathrm{y} /$ regulation legislation/icdra/PL5-3.pdfaccessed on September 22, 2016

115 Regulation of similar biotherapeutic products in Latin America, GABI, http://www.gabionline.net/Biosimilars/Research/R egulation-of-similar-biotherapeutic-products-inLatin-Americaaccessed on September 22, 2016

116 Similar biotherapeutic products approved and marketed in Latin America, GABI, http://www.gabionline.net/Biosimilars/General/Si milar-biotherapeutic-products-approved-andmarketed-in-Latin-Americaaccessed on November 21, 2016

117 First biosimilar of Latin America, http://www.investe.sp.gov.br/noticia/eurofarmaregistra-primeiro-biossimilar-da-americalatina/accessed on September 22, 2016

118 ANVISA Brazil, April 2014, http://portal.anvisa.gov.br/resultado-debusca? $p \_p \_i d=101 \& p \_p$ lifecycle $=0 \& p \_p \_$state $=$ maximized $\& p \_$mode $=$view \& $p \_$col $i d=$ colum $\underline{\mathrm{n}-}$

$1 \& p$ p col count $=1 \& 101$ struts action $=\% 2$ Fass et publisher $\% 2$ Fview content\& 101 assetEntryI $\mathrm{d}=219797 \& 101$ type $=$ content\& 101 groupId $=2$ 19201\& 101 urlTitle=primeiro-medicamentobiologico-por-comparabilidade-e-registrado-pelaanvisa\&redirect $=\mathrm{http} \% 3 \mathrm{~A} \% 2 \mathrm{~F} \% 2 \mathrm{Fportal}$.anvisa.g ov.br\%2Fresultado-de-

busca $\% 3$ Fp p id $\% 3$ D 3 $\% 26 \mathrm{p}$ p lifecycle $\% 3 \mathrm{D} 0 \%$ $26 \mathrm{p} \_\mathrm{p}$ state $\% 3$ Dnormal $\% 26 \mathrm{p} \_\mathrm{p} \_$mode $\% 3 \mathrm{Dview}$ $\% 26 \mathrm{p}$ p col id $\% 3$ Dcolumn-

$1 \% 26 \mathrm{p} p \mathrm{p}$ col count $\% 3 \mathrm{D} 1 \% 263$ advancedSearc h\%3Dfalse $\% 26$ 3 groupId $\% 3$ D0 $\% 26 \_3$ keyword s\%3Dremsima $\% 263$ assetCategoryIds \%3D2969 $01 \% 263$ delta $\% 3 \mathrm{D} 20 \% 263 \mathrm{cur} \% 3 \mathrm{D} 1 \% 263 \mathrm{~s}$ truts action $\% 3 \mathrm{D} \% 252 \mathrm{Fsearch} \% 252 \mathrm{Fsearch} \% 26$ 3 format $\% 3 \mathrm{D} \% 263$ assetTagNames $\% 3$ Dmedica mento $\% 263$ andOperator $\% 3$ Dtrue $\% 263$ form Date\%3D1441824476958\&inheritRedirect=trueac cessed on September 22, 2016

119 Biosimilars of rituximab, GABI, http://gabionline.net/layout/set/print/content/view/ full/3729accessed on September 22, 2016

120 New Drug Approvals, https://newdrugapprovals.org/tag/etanercept/acces sed on September 22, 2016

121 Colombia, BRIC WALL, https://bricwallblog.com/tag/colombia/accessed on September 22, 2016

122 New monoclonal antibody biosimilars approved in 2015 in Latin America, GABI, http://gabijournal.net/new-monoclonal-antibody-biosimilarsapproved-in-2015-in-latin-america-positionstatement-of-the-latin-american-forum-onbiosimilars-in-biosimilarity-interchangeabilityand-extrapolation-of-indicatio.htmlaccessed on September 22, 2016 
123 Historical development of CIGB products approved for commercialization, Nature, http://www.nature.com/nbt/journal/v25/n11/fig ta b/nbt1107-1215 T1.htmlaccessed on September 22, 2016

124 Nimotuzumab, In Wikipedia, The Free Encyclopedia, from https://en.wikipedia.org/w/index.php?title=Nimotu zumab\&oldid $=751276385$ accessed on September 22, 2016

125 Regulation of biosimilar medicines, Version 2.0, https://www.tga.gov.au/sites/default/files/evaluatio n-biosimilars-151217 0.pdfaccessed on September 23, 2016

126 Biosimilars of epoetin alfa, GABI, http://gabionline.net/Biosimilars/General/Biosimil ars-of-epoetin-alfaaccessed on September 23, 2016

127 Epoetin alfa biosimilar- Sandoz, AdisInsight, http://adisinsight.springer.com/drugs/800037703ac cessed on September 23, 2016

128 Biosimilars approved in Australia, GABI, http:/www.gabionline.net/Biosimilars/General/Bi osimilars-approved-in-Australiaaccessed on November 21, 2016

129 Basalgar, https://www.basaglar.com/accessed on September 23, 2016

130 Bemfola, Finox Biotech, http://finoxbiotech.com/finox-biotechs-bemfolareceives-marketing-authorisation-in-australia-fortreatment-of-infertility/accessed on September 23, 2016

131 INFLECTRA infliximab (rmc) 100mg Powder for Injection vial, TGA Australia, https://www.tga.gov.au/artg/artg-id217066accessed on September 23, 2016

132 NIVESTIM filgrastim (rbe) 300 microgram $/ 0.5 \mathrm{~mL}$ injection solution pre-filled syringe, TGA Australia,

http://search.tga.gov.au/s/search.html?collection=t ga-artg\&profile $=$ record\&meta $i=160108$ accessed on September 23, 2016

133 TEVAGRASTIM filgrastim 480 microgram $/ 0.8 \mathrm{~mL}$ injection, TGA Australia, http://search.tga.gov.au/s/search.html?collection $=\mathrm{t}$ ga-artg\&profile $=$ record\&meta $i=163677$ accessed on September 23, 2016

134 ZARZIO filgrastim (rbe) 300 microgram $/ 0.5 \mathrm{~mL}$ solution for injection pre-filled syringe, TGA Australia,

http://search.tga.gov.au/s/search.html?collection=t ga-artg\&profile $=$ record\&meta $i=195066$ accessed on September 23, 2016

135 OMNITROPE somatropin (rbe) $5 \mathrm{mg} / 1.5 \mathrm{~mL}$ injection cartridge, TGA Australia, http://search.tga.gov.au/s/search.html?collection=t ga-artg\&profile $=$ record\&meta $i=82211$ accessed on September 23, 2016

136 SCITROPIN A somatropin (rbe) $10 \mathrm{mg} / 1.5 \mathrm{~mL}$ solution for injection cartridge, TGA Australia,http://search.tga.gov.au/s/search.html?co $\underline{\text { lection }=\text { tga- }}$ artg\&profile $=$ record\&meta $\mathrm{i}=162529$ accessed on September 23, 2016

137 Rituximab, TGA, https://www.tga.gov.au/sites/default/files/ausparrituximab-150827.docxaccessed on September 23, 2016

138 Trastuzumab (Herceptin), Cancer Australia, https://canceraustralia.gov.au/affectedcancer/cancer-types/breast-cancer/treatment/whatdoes-treatment-breast-cancer-involve/targetedtherapies/types-targeted-therapy/trastuzumabherceptinaccessed on September 23, 2016

139 Avastin, Roche Australia, http://www.rocheaustralia.com/home/products/pharmaceuticals/avas tin.htmlaccessed on September 23, 2016

140 Australian public assessment report for Ranibizumab, TGA, https://www.tga.gov.au/sites/default/files/ausparranibizumab-141014.docxaccessed on September 23, 2016

141 Australian Public Assessment Report for Adalimumab, TGA, https://www.tga.gov.au/auspar/ausparadalimumab-rch-1 accessed on September 23, 2016

142 Australian Public Assessment Report for Etanercept, TGA, https://www.tga.gov.au/sites/default/files/ausparetanercept-150923.pdfaccessed on September 23, 2016

143 Ghosh PK, Biotechnology Industries in India in Industrial Biotechnology Ed.:V.S . Malik and Padma Sridhar, 1992, Pub.: Oxford \& IBH Publishing Co Pvt. Ltd, New Delhi, (ISBN 81-2040710-5), pp 71-99, http://www.gandipsbio.com/article/1992 Industria 1 Biotechnology.pdf

144 Hepatitis B, Serum Institute India, http://www.cdsco.nic.in/writereaddata/Serum\%20I nstitute $\% 20$ Hep B.pdfaccessed on September 26, 2016

145 Ghosh PK, Indian Efforts for Developing Biotechnology, Asian Biotechnology and Development Review, Vol. 11 No. 1, pp 35-56, http://ris.org.in/images/RIS images/pdf/article2 _v $11 \mathrm{n} 1 . \mathrm{pdf}$

146 India Similar Biologics Guidelines 2012, http://www.cdsco.nic.in/writereaddata/Bio\%20Si milar\%20Guideline.pdfaccessed on September 26, 2016

147 India Similar Biologics Guidelines 2016, http://cdsco.nic.in/writereaddata/Proposed\%20Gui delines $\% 20$ for $\% 20$ Similar $\% 20$ Biologic $\% 202016$. pdfaccessed on September 26, 2016

148 Ghosh PK, The Rules for Handling Transgenic Organisms and Biopharmaceuticals Produced Therefrom in India, June 2003,J.of Sci. \& Ind. Res., Vol. 62, pp 554-572, http://nopr.niscair.res.in/bitstream/123456789/262 98/1/JSIR $\% 2062(6) \% 20554-572 . p d f$

149 Similar Biologics approved and marketed in India, GABI, 
http://www.gabionline.net/Biosimilars/General/Si milar-biologics-approved-and-marketed-inIndiaaccessed on November 21, 2016

150 Hepatitis $\mathrm{B}$, DrugsUpdate, http://www.drugsupdate.com/brand/generic/Vacci ne,HepatitisB/9020accessed on September 26, 2016

151 Genevac, Serum Institute, http://www.seruminstitute.com/content/products/p roduct genevac.htmaccessed on September 26, 2016

152 Hepatitis B, Biological Evans, http://www.biologicale.com/pdf/ProductList.pdfac cessed on September 26, 2016

153 Hepatitis B, Wockhardt, http:/www.drugsupdate.com/brand/generic/Vacci ne,HepatitisB/4084accessed on September 26, 2016

154 Revac, Bharat Biotech, http://www.bharatbiotech.com/products/vaccines/r evac-b-mcf/accessed on September 26, 2016

155 Emgrast, DrugsUpdate, http:/www.drugsupdate.com/brand/generic/Filgra stim/37631 accessed on September 26, 2016

156 Fegrast, Meds Plan, http://www.medsplan.com/DrugsDetailsPage/FEG RAST-300IU-INJECTION/Filgrastimaccessed on September 26, 2016

157 Frastim, Drugs Update, http://www.drugsupdate.com/brand/generic/Filgra stim/12846accessed on September 26, 2016

158 Grafeel PFS, Drugs Update, http://www.drugsupdate.com/brand/generic/Filgra stim/643accessed on September 26, 2016

159 Neukine, Drugs Update, http://www.drugsupdate.com/brand/generic/Filgra stim/37633accessed on September 26, 2016

160 Nufil,

Biocon, http://www.biocon.com/docs/prescribing informat ion/oncology/nufilsf pi.pdfaccessed on September 26, 2016

161 Religrast, Reliance Life Sciences, http://www.rellife.com/products religrast.htmlacc essed on September 26, 2016

162 Neupeg, Intas, http://www.intaspharma.com/index.php?option=co $\underline{\mathrm{m} \text { djcatalog } 2 \& \text { view }=\text { itemstable } \& \text { cid }=2 \& \text { Itemid }=7}$ 8accessed on September 26, 2016

163 Pegex, Drugs Update, http:/www.drugsupdate.com/brand/generic/Pegfil grastim/46461accessed on September 26, 2016

164 Peg-Grafeel, Drugs

Update, http://www.drugsupdate.com/brand/generic/Pegfil grastim/46462accessed on September 26, 2016

165 EPOREC, Intas, Meds Plan, http://www.medsplan.com/DrugsDetailsPage/EPO REC-4000IU/Erythropoietinaccessed on September 26, 2016

166 Repoitin, Serum Institute, http://www.seruminstitute.com/content/products/p roduct repoitin.htmaccessed on September 26, 2016
167 Shanpoietin, Drugs Update, http://www.drugsupdate.com/brand/generic/Erythr opoietin/425accessed on September 27, 2016

168 Zyrop, MedIndia, http://www.medindia.net/drugprice/erythropoietin/zyrop-4000-i-u.htm

169 Ceriton, Drugs Update, http://www.drugsupdate.com/brand/generic/Erythr opoietin/415accessed on September 27, 2016

170 Cadicrit, Cadila Pharma, http:/cadilapharma.com/cadila_products/cadicrit4000-iu-inj/

accessed on September 27, 2016

171 Epofer, Med India, http://www.medindia.net/drugprice/erythropoietin/epofer-4000-i-u.htmaccessed on September 27, 2016

172 Epofit/Erykine, Intas, http://www.intaspharma.com/index.php?option $=$ co $\underline{\mathrm{m} \text { djcatalog} 2 \& \text { view }=\text { itemstable } \& \text { cid }=2 \& \text { Itemid }=7}$ 8accessed on September 27, 2016

173 Erypro Prefilled, Biocon, http://www.biocon.com/docs/prescribing informat ion/nephrology/eryproprefilled pi.pdfaccessed on September 27, 2016

174 Relipoietin, Med India, http://www.medindia.net/drugprice/erythropoietin/relipoietin-4000iu.htmaccessed on September 27, 2016

175 Wepox, Wockhardt, http://www.wockhardt.com/products/searchproducts.aspxaccessed on September 27, 2016

176 Actorise, MedPlus Mart, http://www.medplusmart.com/product/ACTORIS E-25MCG-INJECTION/ACTO0011accessed on September 27, 2016

177 Cresp, Med India, http://www.medindia.net/drugprice/darbepoetin-alfa/cresp-40-mcg.htmaccessed on September 27, 2016

178 Darbatitor, Torrent Pharma, http://www.torrentpharma.com/thp nephrology.ph paccessed on September 27, 2016

179 Regen D, Bharat Biotech, http://www.bharatbiotech.com/products/biotherapeutic/regen-d/accessed on September 27, 2016

180 Myokinase, Biocon, http://www.biocon.com/docs/prescribing informat ion/cardiology/myokinase pi.pdfaccessed on September 27, 2016

181 Shankinase, Drugs Update, http://www.drugsupdate.com/brand/generic/Strept okinase/3565accessed on September 27, 2016

182 Biocon, http://www.biocon.com/accessed on September 27, 2016

183 Wosulin, Wockhardt Search Products, http://www.wockhardt.com/products/searchproducts.aspxaccessed on September 27, 2016

184 Human Actrapid, http://www.novonordisk.co.in/content/dam/India/ AFFILIATE/www-novonordisk-coin/Home/Commons/PDF/Public\%20Notice $\% 2020$ $160422 \% 20(1)$.pdfaccessed on September 27, 2016 
185 Humulin, Eli Lilly, http://www.humulin.com/other-humulinproducts.aspx\#pen-raccessed on September 27, 2016

186 Huminsulin, Eli Lilly, https://www.lillyindia.co.in/_Assets/PDFViewer/v iewer.html?file=../pdf/Product/Huminuslin-R40IU_Gland-vials.pdfaccessed on September 27, 2016

187 Basalog, MEDGUIDEINDIA, http://www.medguideindia.com/find brand by sa mepid.php? similarpid $=2847,2848,2849,2850,2967$ ,2968,2969,2970accessed on September 27, 2016

188 Glaritus, Wockhardt, http://www.wockhardt.com/products/searchproducts.aspxaccessed on September 27, 2016

189 Novorapid, MEDINDIA, http://www.medindia.net/drug-price/insulinlispro/novorapid-penfill-100-iu.htmaccessed September 27, 2016

190 Humalog, https://www.lillyindia.co.in/_Assets/PDFViewer/v iewer.html?file=../pdf/Product/Humalog-Mix-25Cartridges.pdfaccessed on September 27, 2016

191 Human Actrapid, Drugs Update, http://www.drugsupdate.com/brand/generic/Insuli $\underline{\mathrm{n} / 12759}$ accessed on September 27, 2016

192 Macrogen, Drugs Update, http://www.drugsupdate.com/brand/showavailable brands/1282accessed on September 27, 2016

193 Emcure

Oncocare, http://www.emcure.co.in/products Oncocare.aspa ccessed on September 27, 2016

194 Interferon alfa-2a, Taj Pharma, http://tajpharma.com/interferon-alpha-2a-genericstaj-pharmaceuticals.htmaccessed on September 27, 2016

195 Pegasys in India, http://www.hardikmedical.com/pegasys/accessed on September 27, 2016

196 Genentech Pegasys, http:/www.gene.com/patients/medicines/pegasysa ccessed on September 27, 2016

197 Intalfa,

Intas, http://www.intaspharma.com/index.php?option=co $\underline{\mathrm{m} \text { djcatalog } 2 \& \text { view }=\text { item } \& \mathrm{id}=43: \text { intalfa\&cid }=2: \mathrm{b}}$ iologics\&Itemid $=78$ accessed on September 27 , 2016

198 Reliferon, Reliance Life Sciences, http://www.rellife.com/products reliferon.htmlacc essed on September 27, 2016

199 Shanferon, Drugs Update, http://www.drugsupdate.com/brand/generic/Interfe ronAlfa-2B/1271 accessed on September 27, 2016

200 Zavinex, Drugs Update, http://www.drugsupdate.com/brand/generic/Interfe ronAlfa-2A/24621 accessed on September 27, 2016

201 Pegliton, Drugs Update, http://www.drugsupdate.com/brand/generic/Pegint erferonalfa-2b/47961accessed on September 27, 2016
202 Relibeta, Reliance Life Sciences, http://relibeta.rellife.com/relibeta faqs.htmlaccess ed on September 27, 2016

203 Allface, http://biz.allyface.com/india/suppliers/bizinterferon-gammaaccessed on September 27, 2016

204 Humatrope, Eli Lilly India, https://www.lillyindia.co.in/ Assets/pdf/Product/H umatrope-6mg-and-12-mg-injection.pdfaccessed on September 28, 2016

205 .Eutropin, LG Life Sciences, http://www.lgls.com/prod/product_view.jsp?ke gu bun=EN\&prod_seq $=112$ accessed on September 28,2016

206 Genotropin, Drugs Update, http://www.drugsupdate.com/brand/showavailable brands/838accessed on September 28, 2016

207 Norditropin Nordilet, Drugs Update, http://www.drugsupdate.com/brand/generic/Somat ropin/11049accessed on September 28, 2016

208 Saizen, Drugs Update, http://www.drugsupdate.com/brand/generic/Somat ropin/49184accessed on September 28, 2016

$209 \mathrm{BIOMAb}$ EGFR, Biocon, http://www.biocon.com/biocon_products_bio_BF biomab pa.aspaccessed on September $2 \overline{8}, 2016$

210 Maball,

Hetero, http://heteroworld.com/view news.php?id=459acc essed on September 28, 2016

211 MabTas, Intas, http://www.intaspharma.com/index.php?option $=$ co $\underline{m}$ content\&view $=$ article\&id $=94$ accessed on September 28, 2016

212 Reditux, In Wikipedia, The Free Encyclopedia, https://en.wikipedia.org/w/index.php?title=Reditu $\underline{x}$ \&oldid $=728704487$ accessed on September 29, 2016

213 Ikgdar, Emcure, http://www.emcure.co.in/business_marketing.aspa ccessed on September 29, 2016

214 Baxter India, http://www.baxter.in/healthcare professionals/pro ducts/recombinate.htmlaccessed on September 29, 2016

215 NovoSeven, Pharma Biz, http://saffron.pharmabiz.com/article/detnews.asp? articleid $=52474 \&$ sectionid $=45$ accessed on September 29, 2016

216 Kumar S. Recombinant activated factor VII for acute intracerebral hemorrhage. Indian J Crit Care Med 2005;9, pp 11-3, http://www.ijccm.org/article.asp?issn=0972$\underline{5229}$; year $=2005 ;$ volume $=9 ;$ issue $=1 ;$ spage $=11$; epa $\mathrm{ge}=13$; aulast $=$ Kumaraccessed on September 29, 2016

217 Folisurge, Intas Pharma, http://www.intaspharma.com/index.php?option=co $\underline{\mathrm{m} \text { djcatalog} 2 \& \text { view }=\text { itemstable \&cid }=2 \& \text { Itemid }=7}$ 8accessed on September 29, 2016

218 FostiRel, Reliance Life Sciences, http://www.rellife.com/products fostirel.htmlacce ssed on September 29, 2016 
219 Terifrac, $\quad$ Intas, http://www.terifrac.com/prescribing info.htmlacce ssed on September 29, 2016

220 AbcixiRel, Reliance Life Sciences, http://www.rellife.com/products_abcixirel.htmlacc essed on September 30, 2016

221 Adfrar, Evaluate Group, http://www.evaluategroup.com/Universal/View.as px?type $=$ Story $\& i d=618431$ accessed on September 30, 2016

222 Exemptia, Zydus Cadila, http://exemptia.com/accessed on September 30, 2016

223 CanMab,

Biocon, http://www.biocon.com/biocon products bio BF canmab.aspaccessed on September 30, 2016

224 Choriorel, Reliance Life Sciences, http://www.rellife.com/products choriorel.htmlacc essed on September 30, 2016

225 Luveris-Merck India, http://www.merckserono.in/en/therapy areas/fertil ity/luveris/luveris.htmlaccessed on September 30, 2016

226 Human recombinant serum albumin, Bharat Biotech, http://www.bharatbiotech.com/rd/rdpipeline/accessed on September 30, 2016

227 Erbitux, Drugs Update, http://www.drugsupdate.com/brand/showavailable brands/944accessed on September 30, 2016

228 Etacept, http://www.ciplamed.com/content/etaceptinjectionaccessed on September 30, 2016

229 IntaCept, Intas, http://intacept.in/aboutus/accessed on September 30, 2016

230 Infimab, Pharma Biz, http://www.pharmabiz.com/NewsDetails.aspx?aid $=85412 \&$ sid $=2$ accessed on September 30, 2016

231 Rasburicase, Med Ind, http://medind.nic.in/ici/t14/i2/icit14i2p180.htmacc essed on September 30, 2016

232 Razumab, Business http://www.businessstandard.com/article/companies/intas-becomesfirst-global-company-to-launch-a-biosimilarversion-of-lucentis115061900567 1.htmlaccessed on September 30, 2016

233 South Korean Guidelines on evaluation of biosimilar products, http://www.mfds.go.kr/eng/eng/download.do;jsess ionid=1G1QR0t7aL9tTt15gw0vau8Gxe8GjdXgIjc 7At8rrdQ0DEVMQV6NZFVTWdMVhDqN?boar $\underline{\mathrm{dCode}}=17840 \&$ boardSeq $=70199 \&$ fileSeq $=1$ acces sed on October 10, 2016

234 Korean Regulations for Biosimilars, GABI, http://gabi-journal.net/korean-regulations-forbiosimilars.htmlaccessed on October 10, 2016

235 Brenzys, Merck, http://www.merck.com/licensing/ourpartnership/samsung-bioepis.htmlaccessed on October 10, 2016
236 Brenzys, $\quad$ GABI, http://www.gabionline.net/Biosimilars/General/Bi osimilars-approved-in-South-Koreaaccessed on October 10, 2016

237 Davictrel, Adis Insight, http://adisinsight.springer.com/drugs/800036821 ac cessed on October 10, 2016

238 Herzuma, Celltrion, https://www.celltrion.com/en/pr/reportDetail.do?s eq $=324$ accessed on October 10, 2016

239 Omnitrope, Sandoz, http://www.omnitrope.com/accessed on October 10,2016

240 Remsima, Celltrion, http://www.celltrionhealthcare.com $/ 02$ products $/ \mathrm{p}$ roducts01.aspaccessed on October 10, 2016

241 Renflexis, Merck, http://www.mercknewsroom.com/newsrelease/corporate-news/merck-announcessamsung-bioepis-receives-approval-renflexisinfliximab-baccessed on October 10, 2016

242 CMS Law, A comparison of European and Chinese regulation of biosimilar products, http://www.cmslawnow.com/ealerts/2015/10/a-comparison-ofeuropean-and-chinese-regulation-of-biosimilarproductsaccessed on October 12, 2016

243 Wang K, Biosimilars are Regulated Differently in China,

PharmaDJ, https://www.ropesgray.com/ /media/Files/articles/ 2015/May/20150529-Biosimilars-RegulationsWang.ashxaccessed on October 12, 2016

244 China Biosimilar Guidelines News, GABI, http://www.gabionline.net/layout/set/print/content/ view/full/2236accessed on October 12, 2016

245 Tang Y, Biotechnology in China, VBU, June 2004, https://dechema.de/dechema media/chinesebiotec h-view image-1-called by-dechema-original sitedechema_eV-original_page-124930.pdfaccessed on October 12, 2016

246 Shenzhen Kexing, http://www.kexing.com.cn/products.aspx\#accesse d on October 12, 2016

247 Hapgen, $\quad$ Tri-Prime, http://www.triprime.com/en/second.aspx?nodeid= 293accessed on October 12, 2016

248 Shenzhen Kangtai, http://biokangtai.com/doce/aboutusdefault.htmlaccessed on October 12, 2016

249 JILIFEN, http://en.china-gene.com/product/prodetail.jsp?id=7372accessed on October 12, 2016

250 Genetime, http://www.watsin.com.cn/english/En Product.asp ?BigClassName $=\% \mathrm{BD} \% \mathrm{~F} 0 \% \mathrm{D} 2 \% \mathrm{~F} 2 \% \mathrm{CA} \% \mathrm{E} 6 \mathrm{ac}$ cessed on October 12, 2016

251 GeneSoft, http://www.watsin.com.cn/english/En_Product.asp ?BigClassName $=\%$ BD $\%$ F0\%D2\%F2\%EB $\% \mathrm{C} 4 \mathrm{ac}$ cessed on October 12, 2016

252 Zhou EY,Top 60 Chinese Biofirms Propel Industry Forward, GEN News, Feb 15, 2008 (Vol. 28, No. 4), www.genengnews.com/gen-articles/top-60- 
chinese-biofirms-propel-industry-

forward/2367/accessed on October 12, 2016

253 Chen $\mathrm{H}$ and Lin $\mathrm{Y}$, Rise of private health insurance,

http://www.chinaeconomicreview.com/node/5667 Oaccessed on October 12, 2016

254 ASEAN Infographics: population, marker economy, http://aseanup.com/asean-infographicspopulation-market-economy/accessed on October 17,2016

255 ASEAN Economic Community Blueprint, ASEAN, 2008 (ISBN 978-979-3496-77-1), pp 156 , http://asean.org/wpcontent/uploads/archive/5187-10.pdf

256 Menon J and Melendez AC,Realizing an Asean Economic Community: Progress and Remaining Challenges, ADB Economics Working Paper Series, No. 432, May 2015, https://www.adb.org/sites/default/files/publication/ 160067/ewp-432.pdfaccessed on October 17, 2016

257 The ASEAN Common Technical Dossier (ACTD) for the registration of pharmaceuticals for human use,

http://www.hsa.gov.sg/content/dam/HSA/HPRG/ Western Medicine/Overview Framework Policie s/Guidelines_on_Drug_Registration/ACTD_Orga nizationofDossier.pdfaccessed on October 17, 2016

258 Lakkis MM, The ASEN Harmonization Scheme: Another CTD- Another Challenege to the Industry, November 2008, pp 39-43, www.raps.org/workarea/downloadasset.aspx? $\mathrm{id}=4$ $\underline{093}$

259 Ministry Of Health Malaysia, National Pharmaceutical Control Bureau, http://npra.moh.gov.my/images/Guidelines_Centra 1/Guidelines on Regulatory/GUIDELINES\%20F OR\%20REGISTRATION\%200F\%20BIOSIMIL AR\%20(1).pdfaccessed on October 17, 2016

260 Singapore Biosimilar Guidelines, http://www.hsa.gov.sg/content/dam/HSA/HPRG/ Western Medicine/Overview Framework Policie s/Guidelines on Drug Registration/Appendix $\% 2$ 017 Guidance $\% 20$ on $\% 20$ Registration $\% 20$ of $\% 20$ Similar\%20Biological\%20Products $\% 20 \mathrm{in} \% 20 \mathrm{Sin}$ gapore\%202011.pdfaccessed on October 17, 2016

261 Philippines Biosimilar Guidelines, http://www.fda.gov.ph/attachments/article/151256 /Administrative $\% 20$ Order $\% 20$ No. $\% 202014-$ 0016\%20-\%20Biosimilars.pdfaccessed on October 17,2016

262 Adcock A, Biosimilars in Thailand, Tilleke \& Gibbins, http://www.tilleke.com/resources/biosimilarsthailandaccessed on October 17, 2016

263 Regulation of Biologics in Malaysia, GABI, http://gabi-journal.net/regulation-of-biologics-inmalaysia.htmlaccessed on October 20, 2016

264 Scitropin, http://www.gmedication.com/?s=scitropin\%20aac 265 cessed on October 20, 2016

Binocrit,http://www.ema.europa.eu/ema/index.jsp ?curl=pages $/$ medicines $/$ human $/$ medicines $/ 000725 /$ human med 00065.jsp\&mid=WC0b01ac058001d 124accessed on October 20, 2016

266 Zarzio, https://www.medicines.org.uk/emc/medicine/2231 0accessed on October 20, 2016

267 Nivestim, EMA, http://www.ema.europa.eu/docs/en_GB/document library/EPAR -

Public assessment report/human/001142/WC50 0093664.pdfaccessed on October 20, 2016

268 Insugen, Biocon, http://biocon.com/docs/prescribing information/di abetology/insugen3070refil_pi.pdf accessed on October 20, 2016

269 Hemapo, MIMS, http://www.mims.com/indonesia/drug/info/hemap o\#Contentaccessed on October 20, 2016

270 Leucogen, MIMS, http://www.mims.com/indonesia/drug/info/leucog enaccessed on October 20, 2016

271 Commonwealth of Independent States, In Wikipedia, The Free Encyclopedia, https://en.wikipedia.org/w/index.php?title $=$ Comm onwealth of Independent States\&oldid $=7416935$ 88accessed on October 20, 2016

272 Russian Federation Federal Law on Circulation of Medicines, https://www.unodc.org/res/cld/document/rus/feder al-law-on-circulation-ofmedicines_html/Russian_Federation_Federal_Law On Circulation of Medicines 61FZ_EN.pdfaccessed on October 20, 2016

273 Russian Federation Federal Law on Circulation of Medicines page no. 27, https://www.unodc.org/res/cld/document/rus/feder al-law-on-circulation-ofmedicines_html/Russian_Federation_Federal_Law On Circulation of Medicines 61FZ EN.pdf\#page $=27$ accessed on October 20, 2016

274 Malik M, Tjulandin S and Gilberto de Lima Lopes $\mathrm{G}$ de L, Biosimilars in Low- and Middle-Income Markets: A Case Study of India and Russia, ASCO, https://am.asco.org/biosimilars-low-and-middleincome-markets-case-study-india-andrussiaaccessed on October 20, 2016

275 Availability of Biosimilar Pathways and Data/Marketing Exclusivity Globally: Update, https://bricwallblog.com/2014/06/20/availabilityof-biosimilar-pathways-and-datamarketingexclusivity-globally-update/accessed on October 20, 2016

276 The Treaty on Long-Term Cooperation: Kazakhstan, www.dari.kz/upload/images/downloads/prikazy/or der_735_eng.docaccessed on October 20, 2016

277 Cancer in Developing Countries, INCTR, http://www.inctr.org/about-inctr/cancer-indeveloping-countries/

278 List of African countries by population, In Wikipedia, The Free Encyclopedia, https://en.wikipedia.org/w/index.php?title=List of 
African_countries_by_population\&oldid $=741600$ 329accessed on October 20, 2016

279 Biosimilars by Region, Quintiles, http://www.quintiles.com/microsites/biosimilarsknowledge-connect/biosimilars-by-region/subsaharan-africaaccessed on October 25, 2016

280 Biosimilar Medicines Quality, Non-Clinical and Clinical Requirements, Medicines Control Council, August 2014 , http://www.mccza.com/documents/d259816c2.30 Biosimilars Aug14_v3.pdfaccessed on October 25, 2016

281 Ruff P, Regulation and Funding of Medicines in South Africa, ASCO, May 2015, https://am.asco.org/regulation-and-fundingmedicines-south-africaaccessed on October 25, 2016

282 Egypt Guidelines for Biological Products, http://www.eda.mohealth.gov.eg/Files/656 Guidel ines $\% 20$ For $\% 20$ Registration $\% 20$ of $\% 20$ Biosimilar $\% 20$ Products $\% 20 \mathrm{in} \% 20$ Egypt.pdfaccessed on October 25, 2016

283 Arab Republic of Egypt: Decree No 297 of 2009, http://www.eda.mohealth.gov.eg/Files/757_Minist rial Decree 2972009 En.PDFaccessed on October 25, 2016

284 Mohamed AAF, Government Regulatory Policy towards the Biopharmaceutical Sector: Regulatory Outlook on Biosimilars in Egypt, The American University in Cairo, pp 1-115, http://dar.aucegypt.edu/bitstream/handle/10526/35 74/Microsoft $\% 20$ Word $\% 20$ \%20Thesis_Biopharma_Biosimilar_Regulatory_P olicy Egypt 30 May.pdf? sequence $=1$ accessed on October 25, 2016

285 Epojet, $\quad$ MyHealthBox, https://myhealthbox.eu/el/ $\% \mathrm{CF} \% 86 \% \mathrm{CE} \% \mathrm{AC} \% \mathrm{C}$ F\%81\%CE \%BC\%CE\%B1\%CE\%BA \%CE\%BF/e pojet/2579125accessed on October 25, 2016

286 Epoform, EIPICO, http:/www.eipico.com.eg/images/products/EPOF ORM.htmlaccessed on October 25, 2016

287 Epoetin Sedico, SEDICO, http:/www.sedico.net/English/Products/WebPage s/Epoetin2000\&4000/Epoetin2000\&4000_e.htmac cessed on October 27, 2016

288 Filgrastim, SEDICO, http://www.sedico.net/English/Products/WebPage s/Filgrastim/Filgrastim_e.htmaccessed on October 27,2016

289 Insulin $\mathrm{H} \quad \mathrm{BIO} \quad \mathrm{NPH}, \quad$ SEDICO, http://www.sedico.net/English/Products/WebPage s/Insulin/InsulinHBioNph e.htmaccessed on October 27, 2016

290 Insulin $\mathrm{H}$ BIO R, SEDICO, http:/www.sedico.net/English/Products/WebPage s/Insulin/InsulinHBioR e.htmaccessed on October 27,2016

291 Insulin $\mathrm{H}$ MIX, SEDICO, http://www.sedico.net/English/Products/WebPage s/Insulin/InsulinHBioMix30-70_e.htmaccessed on October 27, 2016
292 Egyptian Ministry of Health Central Administration for Pharmaceutical Affairs, Drug Shortage List, http://www.eda.mohp.gov.eg/Files/892 DS April 2016.pdfaccessed on October 27, 2016

293 Reiferon, Rhein-MinaPharm, http://www.rheinminapharm.com/reiferon.aspaccessed on October 27, 2016

294 Reiferon Retard, MinaPharma, http://www.minapharm.com/public/ProductDetails .aspx?langParam $=$ en \&ProductCode=REIFERETA Raccessed on October 27, 2016

295 EPIGONAL, Egyptian Drug Authority, www.eda.mohealth.gov.eg/Files/458 FOR\%20PU BLISHING.xlsaccessed on October 27, 2016

296 FSH, SEDICO FSH, http://www.sedico.net/English/Products/WebPage s/F.S.H/fsh e.htmaccessed on October 27, 2016

297 Somatropin, SEDICO Somatropin,http://www.sedico.net/English/Produc ts/WebPages/Somatropin/Somatropin_e.htmaccess ed on October 27, 2016

298 Angikinase, SEDICO Angikinase, http://www.sedico.net/English/Products/WebPage s/AngikinaseVail/urokinase e.htmaccessed on November 02, 2016

299 Sedonase, SEDICO, http://www.sedico.net/English/Products/WebPage s/Sedonase/Streptokinase e.htmaccessed on November 02, 2016

300 Guidelines and Guidance Documents for the Registration of Biosimilars in Nigeria, http://www.nafdac.gov.ng/images/PUBLICATIO NS/DG Speeches/s\%20Presentation $\% 20$ on $\% 20 \mathrm{G}$ uidelines $\% 20$ and $\% 20$ Guidance $\% 20$ Document $\% 20$ on $\% 20$ Registration $\% 20$ of $\% 20$ Biosimilars $\% 20 \mathrm{in} \%$ 20Nigeria.pdfaccessed on October 25, 2016

301 NIFDAC, Filgrastim,Erythropoietin,Insulin and Nigeriabiologics approved marketers in Nigeria, http://www.nafdac.gov.ng/index.php/productregistration/registered-

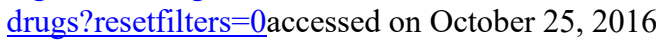

302 Jamison DT, Feachem RG,Makgoba MW, Bos ER, Baingana FK, Hofman KJ, and Rogo KO (Edited) Disease and Mortality in Sub-Saharan Africa. 2nd edition, Washington (DC): The International Bank for Reconstruction and Development / The World Bank;

2006,https://www.ncbi.nlm.nih.gov/books/NBK22 93/accessed on October 25, 2016

303 Lozano R, Naghavi M, Foreman K, Lim S, Shibuya K, Aboyans V, Abraham J, Adair T, Aggarwal R, Ahn SY, Alvarado M, Anderson HR, Anderson $\mathrm{LM}$, Andrews $\mathrm{KG}$, Atkinson $\mathrm{C}$, Baddour LM, Barker-Collo S, Bartels DH, Bell ML, Benjamin EJ, Bennett D, Bhalla K, Bikbov B et al Global and regional mortality from 235 causes of death for 20 age groups in 1990 and 2010: a systematic analysis for the Global Burden of Disease Study, Lancet,2012, 380(9859),pp 2019-2128, 
https://www.ncbi.nlm.nih.gov/pubmed/23245604 accessed on October 25, 2016

304 List of countries of the world, Countries-of the World.com,https://www.countries-oftheworld.com/most-populous-countries.htmlaccessed on November 02,2016

305 Turkey Regulation on the Registration of Medicinal Products for Human Use, http://www.bpms.com.tr/upresimler/ruhsatlandirm a.pdfaccessed on November 02, 2016

306 Mueller LL, Availability of Biosimilar Pathways and Data/Marketing Exclusivity Globally, BRIC WALL,

https://bricwallblog.com/2014/06/20/availabilityof-biosimilar-pathways-and-datamarketing-

exclusivity-globally-updateand

https://bricwallblog.files.wordpress.com/2014/06/t

able2.pdfaccessed on November 02, 2016 